\title{
The Role of Institutional Uncertainty for Social Sustainability of Companies and Supply Chains
}

\author{
Nikolas K. Kelling ${ }^{1} \cdot$ Philipp C. Sauer ${ }^{2} \cdot$ Stefan Gold ${ }^{1} \cdot$ Stefan Seuring ${ }^{1}$
}

Received: 10 April 2019 / Accepted: 3 January 2020 / Published online: 6 April 2020

(c) The Author(s) 2020

\begin{abstract}
Global sourcing largely occurs from so-called emerging markets and developing economies (EMDEs). In these contexts, substantial leverage effects for sustainability in supply chains (SCs) can be expected by reducing adverse impacts on society and minimising related risks. For this ethical end, an adequate understanding of the respective sourcing contexts is fundamental. This case study of South Africa's (SA) mining sector uses institutional theory and the notion of institutional uncertainty to empirically analyse the challenges associated with establishing social sustainability. The case study research is informed by 39 semi-structured interviews with top management representatives and various state and non-state decision makers in SA. Our findings suggest that (social) sustainability in the institutional field is mainly shaped by the Social and Labour Plan institution, induced by state actors and mining companies' practices. However, four weakening factors were identified that adversely affect this regulative institution, drive institutional uncertainty and allow for mining companies' gradual decoupling. Contrastingly, complementing pressures of non-state actors limit institutional uncertainty and push toward mainstreaming the stipulations of the institution. This study contributes to the business ethics literature by providing an in-depth exploration of institutional uncertainty's drivers and barriers within an upstream SC setting and shedding light on multiple actors' interplay and relevance in sector-wide sustainability. The findings are condensed into three main propositions as well as an analytical framework as a basis for follow-up research. This case study helps practitioners understand and manage complexity that results from actor plurality and institutional uncertainty in EMDEs.
\end{abstract}

Keywords Institutional uncertainty $\cdot$ Decoupling $\cdot$ Compliance $\cdot$ Social sustainability $\cdot$ Mineral resources

\section{Introduction}

Electronic supplementary material The online version of this article (https://doi.org/10.1007/s10551-020-04423-6) contains supplementary material, which is available to authorized users.

Nikolas K. Kelling

kelling@uni-kassel.de

Philipp C. Sauer

philippchristopher.sauer@unibz.it

Stefan Gold

gold@uni-kassel.de

Stefan Seuring

seuring@uni-kassel.de

1 Faculty of Economics and Management, University of Kassel, Kleine Rosenstr. 3, 34117 Kassel, Germany

2 Faculty of Science and Technology, Free University of Bozen-Bolzano, Piazza Università, 5, 39100 Bozen-Bolzano, Italy
The 2019 Brazil tailing dam tragedy, the 2013 Rana Plaza building collapse in Bangladesh and the 2012 Marikana mining strike in South Africa (SA) are prominent examples of ethical challenges in supply chains (SCs). Although regulations for preventing such tragedies were in place, they were not effective in these three cases (New York Times 2019; Huq and Stevenson 2018; Rajak 2012). Institutional voids, i.e. absent or weak institutions, are a common issue in emerging markets and developing economies (EMDEs) and have been found to impede the effectiveness of regulation, threaten the sustainability of local operations and consequently threaten the sustainability of related SCs (Huq and Stevenson 2018; Busse et al. 2016b; Silvestre 2015). However, instances such as the mentioned Marikana incident occur in regulated as well as scrutinised industries and are thus not influenced by institutional voids (Arya and Bassi 2011; CALS 2017). Conceptual studies have recently 
proposed an alternative explanation that has marginally been touched upon in the business ethics literature. These studies build on institutional uncertainty-lack of institutions' institutionalisation (Phillips et al. 2009) — that results in ambiguity regarding the institutions and their interpretation. Institutional uncertainty thus ultimately affects the degree to which organisations deliver the social performance expected by the societies in which they are embedded. In effect, institutional uncertainty can offer a way to understand why business organisations fail to provide their expected contributions to society.

Such a lack of social performance on a local level has moreover been found to impact an entire SC's social performance (Golicic et al. 2019; Hofmann et al. 2018; Huq and Stevenson 2018). It is thus vital to understand the respective institutional setting and actors in order to fully comprehend factors that hamper sustainability due to institutional uncertainty and non-compliance. While previous findings were on a conceptual level, scarce empirical research validates a regulative sustainability institution as well as barriers and drivers to institutional uncertainty. Contrasting previous research on this ethical issue (Hofmann et al. 2018; Huq and Stevenson 2018; Blome and Paulraj 2013; Ehrgott et al. 2011), we do not adopt a focal company-centred, buyer-supplier perspective, but rather focus on a wide set of relevant state and non-state actors at the SC's first-tier (Golicic et al. 2019).

We chose the mining sector as a fruitful example for this investigation because mineral commodities represent the original material of manufacturing processes around the globe. At the same time, the mineral sector's and related SCs' social licenses to operate are at stake due to a perceived imbalance among unsustainability and the achieved development at the mine sites (Hofmann et al. 2018; Mayes 2015). Economic development is all too often accompanied by social tensions due to enclave building, low working standards and workers' living standards (Silvestre 2015; Lodhia and Hess 2014; Rajak 2012). To counter these tensions, powerful sustainability institutions are needed to ensure ethical mineral supplies that enable a development impact in the sourcing region (Lodhia and Hess 2014; Solomon 2011).

Mineral extraction and trade can be key pillars for community welfare through social upliftment (Huq et al. 2016; Mayes 2015), but this positive impact is dependent upon the presence of strong institutions and their enforcement (Giurco and Cooper 2012; Solomon 2011). This holds especially true for mineral SCs, which often encompass multiple supplier tiers in numerous countries and contexts (Sauer and Seuring 2019; Young 2015). In order to mitigate risks and enhance sustainability, transparency and traceability up to the raw material stage are helpful (Busse et al. 2016b; Pfohl et al. 2010; Spence and Bourlakis 2009). To achieve contextual understanding, empirical research on the frame conditions of sustainability management and existing institutional loopholes at the upstream parts of global SC is needed to validate the current theoretical body of knowledge (Sauer and Seuring 2018; Busse et al. 2016b). In order to do so, the following research questions (RQs) are proposed:

RQ 1: What is the role of institutional uncertainty for lacking social sustainability?

RQ 2: How is institutional uncertainty created and limited in an institutional field?

To address the RQs, SA represents an interesting case as one of the globally leading mining and mineral exporting countries. As such, SA is the world's largest producer of Platinum Group Metals (PGMs) - among other minerals-with 170,000 direct workers in PGM mines who mined approximately 260 tonnes of precious PGMs in 2018, of which $90 \%$ were exported and used for automobile catalysts and fuel cells (Minerals Council South Africa 2018). Hence, understanding SA's mining sector is vital for many global SCs relying on mineral commodities such as the automotive industry.

The country proactively incorporates regulations on the extractive industry to generate public services that help alleviate society's development challenges. Social and Labour Plans (SLPs) are an interactive regulation between state actors and companies. Together with the related "BroadBased Black Economic Empowerment (BBBEE)", which demands $26 \%$ company ownership for historically disadvantaged people, SLPs shape the social sustainability efforts in SA's mining sector (Franks and Vanclay 2013; Arya and Bassi 2011; CALS 2016, 2017). In this sense, SA cannot be characterised as an EMDE country with institutional voids, i.e. absent institutions (Huq and Stevenson 2018; Silvestre 2015). However, SA is ranked merely 116th in the human development index and is the socially most unequal country in the world, with a Gini coefficient of 0.634. SA moreover possesses an official unemployment rate of approximately 27\% (youth aged 15-24: 50\% rate), which underlines that the country, due to its apartheid history (Hamann and Bertels 2018), nevertheless faces considerable societal challenges (UNDP 2016, 2018; Statistics-South Africa 2015, 2016a, 2016b; World Bank 2016).

The remainder of this study is structured in the following way. First, the theoretical frame of institutional theory and social sustainability in SCs is explained. The subsequent methodology section provides insights into the applied fivestage case study research process. Afterwards, the findings cover companies' prevailing social sustainability institution, its enforcement by multiple actors in the institutional field and institutional uncertainty's role for sustainability. Finally, we discuss our theoretical and managerial implications, 
limitations and future research avenues before concluding the paper.

\section{Conceptualising The Role of Institutional Uncertainty for Lacking Social Sustainability}

The first subsection establishes an understanding of institutional theory and the concept of institutional uncertainty, while the second addresses social performance and its relation with institutional uncertainty. For easier recognisability, the core terms are italicised in the text and summarised in Table 1 at the end of this section.

\section{Understanding Institutions, Institutional Uncertainty and Institutionalisation}

Institutional theory holds that organisations ${ }^{1}$ are under scrutiny from various actor groups and design their practices and structures by considering socio-environmental demands to both gain legitimacy that is vital for a company's survival and for preventing legal sanctions (Bromley and Powell 2012; DiMaggio and Powell 1983; Meyer and Rowan 1977). These demands are encoded in institutions that represent "cognitive, normative, and regulative structures and activities that provide stability and meaning to social behaviour" (Scott 1995, p. 33). Therefore, an institution constitutes an entity whose existence and purpose are easily explained with ready-made accounts. Regulations' institutional elements can be manifested in formal structures, such as organisational and sustainability practices that are distributed across industries and nations (Simpson et al. 2012; DiMaggio and Powell 1983; Meyer and Rowan 1977). Within the sustainability realm, sustainability institutions that are adopted by organisations can be established by state actors (Sayed et al. 2017), such as regulative elements similar to the previously mentioned SLPs required by SA government agencies (Powell and Rerup 2017; Scott 1997).

Nevertheless, institutions have been found to differ from context to context. It is thus important to outline the context under investigation, which is referred to as the institutional field. This "relational space" (Wooten and Hoffman 2013, p. 138) comes into existence through interacting actors that "in the aggregate, constitute a recognised area of institutional life" (DiMaggio and Powell 1983, p. 148). Thus, an institutional field is constituted by actors that are guided by a maturing frame of common rules and practices related to a specific institution (Tracey and Phillips 2011). Therefore, the

\footnotetext{
${ }^{1}$ Please note that the terms "company," "firm," and "organisation" are used synonymously throughout this paper due to the diverse literature base.
}

theoretical perspective is especially useful for framing differing institutional contexts and explaining how these contexts enable the adoption of ethically perceived actions.

The mere formulation of regulations, however, is futile without their enforcement by state or private actors. This enforcement is achieved via the institutional pressures that, in effect, can constrain organisations in their actions, change organisational structures and enforce compliance to institutions, thus leading to isomorphism among organisations (Wijen 2014; Meyer and Rowan 1977). DiMaggio and Powell (1983) defined three institutional pressures that positively correlate with isomorphic change: (1) coercive pressure exerted from (non-) state actors upon which the pressured organisation is dependent; (2) mimetic pressure that drives firms to adopt the characteristics of both nearby organisations as well as company peers and (3) normative pressure by and within companies (e.g. via associations and professionalisation).

Ultimately, an organisation's strive for legitimacy might cause conflicts of interest (Meyer and Rowan 1977). Decoupling of a reported action and a real action might occur among both the institutionalised elements and previously efficiency-orientated practices in an organisation. Since our focus lies within the interface of companies and state actors, we focus on policy-practice decoupling and the resultingly undelivered ethical actions. Hence, non-compliance is constituted by rules that are unimplemented or routinely violated and depends upon the level of existing institutional pressures in the corresponding institutional field (Wijen 2014; Bromley and Powell 2012; Simpson et al. 2012; Meyer and Rowan 1977).

To capture such weakly entrenched institutions, we draw on the institutional uncertainty concept that is often pervasive in EMDE countries (Tracey and Phillips 2011). Institutionalisation denotes the extent to "which social processes, obligations, or actualities come to take on a rule-like status in social thought and action" (Meyer and Rowan 1977, p. 341). Phillips et al. (2009) define institutional uncertainty as "contexts that are composed of institutions that are not well institutionalized" (p. 340); thus, "the low degree of institutionalization results in a high degree of ambiguity and therefore a greater degree of institutional uncertainty" (p. 341). Tracey and Phillips (2011) add that the higher the degree of institutionalisation is-meaning the lower the institutional uncertainty is - the higher the legitimacy cost of deviating from an institution becomes. High institutional uncertainty thus discourages companies' compliance with costly institutions and facilitates some freedom with which to decouple from the institutions (Meyer and Rowan 1977).

The literature on institutional uncertainty outlines potential causes and harmful effects on a theoretical level for both international management (e.g. Phillips et al. 2009) and sustainability in SCs (e.g. Sauer and Seuring 2019; Busse 
et al. 2016b), although empirical evidence on the process of institutionalisation in EMDEs is currently lacking and therefore limits our understanding of its effects (Tracey and Phillips 2011). The same applies for our understanding of the social dimension in SCs (Yawar and Seuring 2017) that further informs our selection and analysis of the respective institution and institutional field.

\section{Social Sustainability in SCs and Its Relation with Institutional Uncertainty}

Although SCs research aims for a global application and sustainability dimensions' comprehensive coverage, there nevertheless exists a lack of empirical research on the social dimension (Marshall et al. 2019; Yawar and Seuring 2017; Quarshie et al. 2016; Hall and Matos 2010), which holds especially true for upstream ethical issues and labour-intensive industries (e.g. mining) as well as EMDEs (Hofmann et al. 2018; Huq and Stevenson 2018; Jia et al. 2018; Yawar and Kauppi 2018; Huq et al. 2016). Moreover, the perspectives of non-classical SC members, such as state actors, non-governmental organisations (NGOs) and communities in EMDE have been deemed beneficial for greater social sustainability in SCs, but are mostly neglected in this research traction (Golicic et al. 2019; Kauppi and Hannibal 2017; Wilhelm et al. 2016; Pagell and Shevchenko 2014).

Furthermore, Quarshie et al. (2016) provided a comprehensive research agenda for social sustainability research in SCs with three relevant gaps for this study. They call for the investigation of cross-sector partnerships (business, government, and/or civil society) since they have been rarely evaluated to see how they complement firm's SC related sustainability strategies (see also Clarke and Crane 2018). In addition and in line with other studies, they suggest drawing on institutional theory as a fruitful lens for analysing ethical policies and practices in SCs (Huq and Stevenson 2018; Sauer and Seuring 2018; Kauppi and Hannibal 2017). Ultimately, they call for the investigation of social and ethical concerns of raw material producers such as impacts on communities and social equality. In effect, Quarshie et al. (2016) criticise the currently narrow focus on single organisations or SC actors, while disregarding those affected such as communities (see also Golicic et al. 2019; Huq et al. 2016; Hall and Matos 2010).

An important part of social sustainability and its aimed for development impact is the "external social performance, which includes community development; reduction in risks of social failures; and the inclusion of marginalized stakeholders" (Huq et al. 2016, p. 23; Klassen and Vereecke 2012). These linkages can create development opportunities (e.g. UN Sustainable Development
Goal 8) in the form of a diversified economy as well as social upgrades, i.e. more favourable living conditions (e.g. employment and infrastructure). However, the degree of beneficial and collaborative linkages through contributions to education, local sourcing, supplier development and contributions to infrastructure are context and industry dependent (Huq and Stevenson 2018; Jain et al. 2017; Sauer and Seuring 2017; Hall and Matos 2010). The creation of such impacting linkages and resulting social performance has been found to be relevant in mineral (Sauer and Seuring 2017; Solomon 2011; Lydall 2009), textile (Huq and Stevenson 2018) and biofuel (Hall and Matos 2010) SCs for fulfilling the ethical requirements of stakeholders (actors) (Golicic et al. 2019).

Summarising the previous arguments, the application of the social performance lens with an upstream SC focus requires further research in three main areas to understand sustainability practices and how their institutionalisation is reflected in (mining) companies' efforts for sustainable development (Golicic et al. 2019; Jain et al. 2017; Busse et al. 2016a; Fessehaie and Morris 2013). First, we need to understand the relevant (regulative) social institutions and the companies' responses to them. Second, non-traditional $\mathrm{SC}$ actors and their interactions need to be investigated to understand their scrutiny of company compliance to regulation. Third, this can be done against the lens of institutional theory and especially institutional uncertainty, since the sustainability institution's implementation is affected by it. Hence, it is essential to understand how this uncertainty is created and limited by the institutional pressures that are exerted in the relevant institutional field, which is the focus of the extant paper.

Since institutional theory represents a multitude of concepts (Palmer et al. 2013) and a "theoretical orientation" (Scott 1997, p. 302), this investigation is informed by the previously introduced theoretical constructs that are summarised in Table 1 and guide the analysis presented in the next section.

\section{Methodology}

To answer the RQs and gather empirical data on institutional uncertainty as well as its creation and limitation, we conduct an embedded case study and follow Stuart et al.'s (2002) five-step case study research process that is outlined below in detail: (1) RQs, (2) research design and research site, (3) data gathering, (4) data analysis and (5) dissemination.

The first step involves defining the research objective, as is done in the introduction with the RQs.

For the second step, a case study design was chosen due to the lack of available empirical data as well as explorative and 
Table 1 Key theoretical concepts and their description

\begin{tabular}{|l|l|}
\hline Term & Descriptions \\
\hline Institutional field & Actors and their interactions guided by a common frame/institution. \\
\hline $\begin{array}{l}\text { Coercive, mimetic, and } \\
\text { normative pressure }\end{array}$ & $\begin{array}{l}\text { Three institutional pressures can enforce compliance to institutions: coercive (state or } \\
\text { non-state actors exert pressure onto organisations), mimetic (organisations model } \\
\text { themselves based on other organisations), and normative (an occupation's } \\
\text { professionalisation). }\end{array}$ \\
\hline Decoupling & $\begin{array}{l}\text { Companies' pretended actions and real actions related to institutions might diverge, } \\
\text { depending on the level of institutional pressure, and result in non-compliance through } \\
\text { rules not adhered. }\end{array}$ \\
\hline $\begin{array}{l}\text { Institutional } \\
\text { uncertainty }\end{array}$ & $\begin{array}{l}\text { Weakly entrenched institutions that are not fully implemented, thus leading to } \\
\text { ambiguity in their role of giving meaning to social action. }\end{array}$ \\
\hline Social performance & $\begin{array}{l}\text { Social performance is achieved, amongst others, through contributions to education, } \\
\text { local sourcing, supplier development, and contributions to infrastructure. }\end{array}$ \\
\hline
\end{tabular}

explanatory characteristics reflected in the RQs. A single case study was chosen due to its extreme and revelatory features (Yin 2014). The mining sector and its companies may be considered an extreme or unusual case due to the lack of transparency and heterogeneity of companies, products and actors in the sector (Fessehaie and Morris 2013; Bloch and Owusu 2012). The consideration of regulative institutions makes this case even more complex and revelatory from an industrial economy perspective, wherein the main importers of SA's minerals sit (Minerals Council South Africa 2018). The research site, the Johannesburg-Pretoria region as SA's economic powerhouse that possesses some of the world's largest mining companies, enables to interview a variety of actors. Thus, we can build a comprehensive picture of SA's mining sector that represents the investigated institutional field. Derived from the literature and purposive as well as theoretical sampling (Silverman 2013), we identified the following groups as relevant: (1) companies/industry actors (IDs), (2) consulting companies (Cs), (3) financial sector actors (FSs), (4) state actors and government departments/organisations (GOs), (5) mining unions (MUs) and (6) NGOs. Communities and buyers were identified by the interviewees as influential actors and then inductively added in the findings. GOs and their regulations are essential for global sourcing in general and mineral sourcing in particular; the research at the intersection of sustainability management and mineral sourcing explicitly includes GOs as influential actors (Sauer and Seuring 2017; Fessehaie and Morris 2013; Bloch and Owusu 2012; Lydall 2009).

During the third step, the six actor groups were given face-to-face interviews during a three-month field stay to gather data (July to September 2016), which yielded 39 transcribed, semi-structured interviews with top management representatives and decision makers (Tables 2 and 3). For the embedded case study design each group represents a unit of analysis and each interviewee an incorporated subunit (Yin 2014; Stuart et al. 2002).

A detailed overview of the received interviewee positions can be found in the table below (An acronym in combination with $\mathrm{A}, \mathrm{B}$ or $\mathrm{C}$ indicates two interviews took place on separate dates. If an acronym is listed more than once, more than one interviewee participated.)

Please note that the following numbered anonymisation codes ID/C/FS/GO/MU/NGO refer to the individual interviewee and the related organisation. The listed acronyms/ interview evidences are sorted by the conducted interview dates, while the most recent are cited first (e.g. ID12, 9 etc./ID9-7 refers to ID9, 8 and 7). The (semi-structured) questionnaire, which can be found shortened in the supplementary material, was pre-tested in the field with two international experts and one local researcher. It was aimed at designing a flexible questionnaire that gives the interviewees enough leeway to express own perspectives instead of being guided and potentially biased by too specific questions (Silverman 2013; Bryman and Bell 2011).

The interviews focused on identifying companies' main institutions and roles in shaping sustainable development in the institutional field. Due to the sensitive topic, face-toface interviews were held at different locations of choice (e.g. offices most often, mines and affected communities) and audio recorded after permission. From a cultural perspective, the appearance plays a prominent role in SA and clothing was depending on the interview situation adjusted to demonstrate credibility (Saunders et al. 2012).

In total, 171 people from 80 organisations were approached. Sometimes different departments within one organisation were contacted simultaneously or snowball

Table 2 Data sample

\begin{tabular}{|l|l|}
\hline Data sample distribution & $\begin{array}{l}\text { 12 IDs (mining companies: 4 PGMs, 2 chromium, 1 gold, 1 copper ore/iron } \\
\text { ore/coal, 1 different base metals, 1 mining association, 1 trading company, 1 } \\
\text { manufacturer), 6 Cs, 6 FSs, 4 GOs, 5 NGOs, and 2 MUs }\end{array}$ \\
\hline Total interviewees & 49 \\
\hline Transcribed interviews & 39 \\
\hline Transcribed audio & $35 \mathrm{~h} 40 \mathrm{~min}$ and $51 \mathrm{sec}(=2,140.51 \mathrm{~min})$ \\
\hline Average interview length & $54.54 \mathrm{~min}$ \\
\hline Transcribed pages & $935 \mathrm{DIN}$ A4 pages \\
\hline
\end{tabular}


Table 3 Data sample by interviewee position

\begin{tabular}{|c|c|c|}
\hline \multirow[t]{3}{*}{$\begin{array}{l}\text { Industry } \\
\text { actors (IDs)/ } \\
\text { companies }\end{array}$} & $\begin{array}{l}\text { Sustainability } \\
\text { manager }\end{array}$ & $\begin{array}{l}\text { ID12 (group head), ID9 (group manager), ID8 (manager), ID6 (group } \\
\text { manager - environment), ID5 (senior executive - environment, } \\
\text { health/legacies), ID3 (senior manager group environment) }\end{array}$ \\
\hline & $\begin{array}{l}\text { Supply chain } \\
\text { manager }\end{array}$ & $\begin{array}{l}\text { ID7 (leader), ID6 (group manager/functional lead), ID4 (strategy and } \\
\text { performance lead), ID1 (group head) }\end{array}$ \\
\hline & Others & $\begin{array}{l}\text { ID11 (managing director), ID10 (group trader), } \\
\text { ID8 (manger risk and compliance), ID2 (director and director of business } \\
\text { development) }\end{array}$ \\
\hline \multirow[t]{2}{*}{$\begin{array}{l}\text { Consulting } \\
\text { company } \\
\text { actors }(\mathrm{Cs})\end{array}$} & Director & $\begin{array}{l}\text { C6 (executive and managing), C5 (managing, technical, and commercial), } \\
\text { C4 (general and senior advisor sustainability, C2 (director), C1 (senior - } \\
\text { sustainability) }\end{array}$ \\
\hline & Others & C3 (head of infrastructure and environmental advisor) \\
\hline \multirow[t]{2}{*}{$\begin{array}{l}\text { Financial } \\
\text { sector actors } \\
\text { (FSs) }\end{array}$} & $\begin{array}{l}\text { Sustainability } \\
\text { manager }\end{array}$ & $\begin{array}{l}\text { FS6A (senior - strategy and reporting, enterprise governance, and } \\
\text { compliance), FS5 (global head - environmental and social management/chair } \\
\text { of the equator principles steering committee) }\end{array}$ \\
\hline & Others & $\begin{array}{l}\text { FS6B (corporate and investment banking - mining and metals banker), FS4 } \\
\text { (PGMs analyst), FS3 (investment officer, global infrastructure and natural } \\
\text { resources - oil, gas, and mining) + FS3 (principal investment officer mining), } \\
\text { FS2 (former director - private equity), FS1 (vice president sub-Saharan } \\
\text { Africa) }\end{array}$ \\
\hline $\begin{array}{l}\text { State actors/ } \\
\text { government } \\
\text { organisations- } \\
\text { departments } \\
\text { (GOs) }\end{array}$ & $\begin{array}{l}\text { Anonymised } \\
\text { high-level } \\
\text { position }\end{array}$ & $\begin{array}{l}\text { Environmental Affairs (GO4), Water \& Sanitation (GO3), Mineral } \\
\text { Resources (GO2), Trade and Industry (GO1) }\end{array}$ \\
\hline \multirow{3}{*}{$\begin{array}{l}\text { Mining } \\
\text { unions (MUs) } \\
\text { and NGO } \\
\text { actors }\end{array}$} & Executive & MU2 (president), MU1 (head), NGO1A (director), \\
\hline & Researcher & NGO4 (head of research), NGO3 (researcher), NGO1B (head of research) \\
\hline & Others & $\begin{array}{l}\text { NGO5 (facilitator and officer), NGO5_miner (mine worker at ID3), NGO2 } \\
\text { (coordinator), NGO1C (chairperson) }\end{array}$ \\
\hline
\end{tabular}

sampling was applied. IDs and GOs were the most challenging actor groups to be convinced of participating in the research. The captured perspectives of multiple actors within one group and among the groups facilitate the identification of patterns in this embedded case study (Stuart et al. 2002).

The detailed questionnaire was not sent to the interviewee beforehand, but information related to the research purpose was given in advance. As indicated in Table 3, in some interviews more than one interviewee participated. Nevertheless, these interviews did not turn out to be a real group interview because one interviewee used to be the main speaker, so they are treated as one interview.

Provided information was summed up or sometimes repeated to reduce bias, capture all given information and increase the reliability of data collection (Saunders et al. 2012 , p. 334). After data gathering, the first author transcribed all interviews with agreed-upon transcription rules which incorporate suggestions by Silverman (2014) as well as Mayring (2000) and rules specifically derived for the EMDE context based on the interview experiences. The rules reflect a focus on the spoken content and specific linguistic or psychological details were marked to put statements into context where needed. The transcribed interviews were fully anonymised and then coded. For data triangulation purposes, we added select mining companies' integrated/sustainability reports as well as select information about standards, guidelines and laws. Hence, we strived for credibility of data analysis through the use of multiple sources of evidence within and beyond the sample as suggested by Riege (2003) and Yin (2014).

During step four (data analysis), abductive reasoning was pursued to evaluate the "theory match" alongside evident patterns in the data and to outline theoretical implications and limitations (Kovács and Spens 2005; Dubois and Gadde 2002). To analyse the data for abductive reasoning, a content analysis was incorporated into the research process. As suggested in the abductive reasoning literature, the analysis combined a deductive and inductive thematic coding for each (sub-) category introduced as italicised terms (compare Table 1-deductive ones) (Ketokivi and Choi 2014; Yin 2014; Kovács and Spens 2005; Dubois and Gadde 2002). The inductive coding complemented the deductive codes 


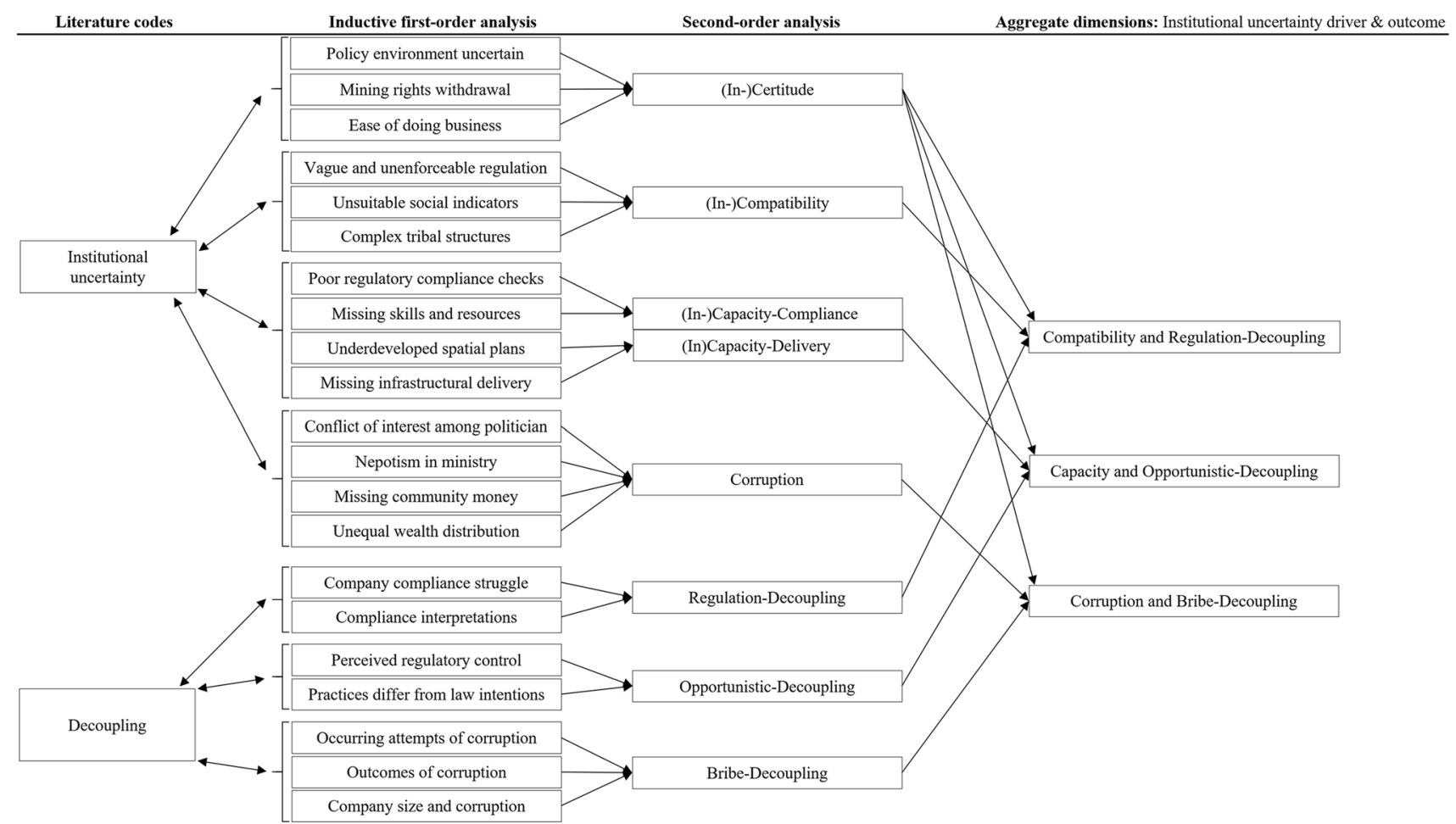

Fig. 1 Coding procedure to determine the connection between institutional uncertainty and decoupling

and condensed the rich data gathered through multiple steps of paraphrasing, reducing and abstracting interview parts to ensure a structured interpretation (Mayring 2015; Gioia et al. 2013). This process was conducted in MAXQDA 12 Pro and dominated by manual coding. In addition, the quantitative content analysis's methodological strengths via autocoding, a keyword-in-context analysis and word frequency and word combination analyses were used to further the understanding of code relations and meanings (Kuckartz 2016; Silverman 2014, 2013). Feedback loops-within the process of analysis-ensured the fit of the theoretical (sub-) categories with the data and categories were adjusted in case of misalignments. This inductive element of category formulation taps the data in order to fill potential category gaps and stimulate theory development (Eisenhardt et al. 2016; Gioia et al. 2013).

Figure 1 illustrates the results of the analysis for institutional uncertainty and decoupling (left column) and how we systematically integrated the first-order (sub-) categories into higher-order categories from which we derived theoretical findings. The first- and second-order analysis was executed on the original text through the above-mentioned condensation process. The involved researchers continuously discussed potential first and second-order codes throughout this analysis and abstraction process until reaching consensus.

Following Gioia et al. (2013) we abstracted this first-order code to derive the different weakening factors inductively and only matched them afterwards with existing literature which led us draw on institutional uncertainty. As displayed in Fig. 1, the abductive research considers data and existing theory in tandem (double arrows). The code relations revealed that second-order themes of institutional uncertainty and decoupling are intertwined and must be regarded together to understand institutional uncertainty in greater depth (right column — aggregate dimensions).

For the fifth and last step (dissemination), Table 4 provides an overview of the four evaluation criteria as well as the strategies and activities that have been used for ensuring high levels of rigour and relevance throughout the research process (Ketokivi and Choi 2014; Yin 2014; Riege 2003; Stuart et al. 2002). 
Table 4 Cross-tabulation of validity/reliability criteria and research phases

\begin{tabular}{|c|c|c|c|c|}
\hline $\begin{array}{l}\text { Criterion/ } \\
\text { research } \\
\text { phase }\end{array}$ & Design & Case selection & Data gathering & Data analysis \\
\hline $\begin{array}{l}\text { Construct } \\
\text { validity }\end{array}$ & $\begin{array}{l}\text { - Five-step } \\
\text { research process } \\
\text { - Questionnaire } \\
\text { built on } \\
\text { theoretical } \\
\text { framework \& } \\
\text { pre-test in the } \\
\text { field }\end{array}$ & $\begin{array}{l}\text { - Interview } \\
\text { group derived } \\
\text { from literature }\end{array}$ & $\begin{array}{l}\text {-Multiple interviewee } \\
\text { groups } \\
\text {-Anonymised } \\
\text { interviews were sent to } \\
\text { interviewees who } \\
\text { requested them } \\
\text {-Different sources of } \\
\text { information (integrated } \\
\text { reports/sustainability } \\
\text { reports, standards, } \\
\text { laws, etc.) } \\
\end{array}$ & $\begin{array}{l}\text { - Data triangulation based on } \\
\text { independent sources } \\
\text { - Chain of evidence displayed in } \\
\text { tables }\end{array}$ \\
\hline $\begin{array}{l}\text { Internal } \\
\text { validity }\end{array}$ & $\begin{array}{l}\text { - Questionnaire } \\
\text { designed by } \\
\text { several } \\
\text { researchers and } \\
\text { SA practitioners } \\
\text { - Applied } \\
\text { theoretical } \\
\text { framework } \\
\end{array}$ & - N/A & $\begin{array}{l}\text { - Well-informed SA } \\
\text { interviewees }\end{array}$ & $\begin{array}{l}\text {-Pattern matching among six } \\
\text { different interviewee groups }\end{array}$ \\
\hline Reliability & $\begin{array}{l}\text { - Case study } \\
\text { protocol with } \\
\text { several involved } \\
\text { researchers }\end{array}$ & $\begin{array}{l}\text { - Transparent } \\
\text { interviewee } \\
\text { groups and } \\
\text { positions } \\
\text { - Justified } \\
\text { research site } \\
\text { selection }\end{array}$ & $\begin{array}{l}\text {-Developed } \\
\text { transcription system } \\
\text { for EMDEs research } \\
\text { contexts } \\
\text {-Database: unified } \\
\text { audio files and } \\
\text { transcripts available } \\
\text {-Detailed data-gathering } \\
\text { protocol }\end{array}$ & $\begin{array}{l}\text { - Involvement of authors who } \\
\text { did not gather data } \\
\text { - Coding agenda and inter-coder } \\
\text { agreement } \\
\text { - Keyword-in-context analysis } \\
\text { and word frequency analysis } \\
\text { - Chain of evidence } \\
\text { demonstrated in the form of } \\
\text { tables and several quotes }\end{array}$ \\
\hline $\begin{array}{l}\text { External } \\
\text { validity }\end{array}$ & $\begin{array}{l}\text { - Theoretically } \\
\text { derived sampling } \\
\text { criteria }\end{array}$ & $\begin{array}{l}\text { Data sample, } \\
\text { research site, } \\
\text { and situation } \\
\text { made } \\
\text { transparent } \\
\end{array}$ & -N/A & $\begin{array}{l}\text { - Analytical generalisation } \\
\text { addressed via abductive } \\
\text { reasoning on a theoretical level } \\
\text { and considering practical } \\
\text { applications }\end{array}$ \\
\hline
\end{tabular}

\section{Findings}

The first section "Social and Labour Plans as Companies' Prevailing Social Sustainability Institution" presents the empirical findings for the regulatory institution SLP and its institutionalisation in the institutional field. We then outline state actors' identified weakening factors as the root cause of institutional uncertainty in the field (section "State Actors' Weakening Factors as Drivers of Institutional Uncertainty") and analyse how companies deal with that uncertainty and decoupling occurs (section "Institutional uncertainty and decoupling"), followed by complementing pressures that aim toward improving social performance and reducing institutional uncertainty (section "Complementing Pressures as Barriers to Institutional Uncertainty"). Finally, section "Resulting Empirical Analysis-Based Framework" delivers a framework and visualises the relations between the theoretical concepts.

\section{Social and Labour Plans as Companies' Prevailing Social Sustainability Institution}

Mining companies operate in a complex legal environment in SA. Within this environment, interviewees regarded SLPs as the prevailing social sustainability institution, interconnected to the BBBEE/Mining Charter (supplementary material). The mining company's contribution to the host community via collaborative development projects-among other labour-related topics-must be disclosed in the respective SLP, which should be aligned with the local development plans. Moreover, SLPs are necessary for companies to be awarded as well as subsequently retain a mining license and mitigate negative social mining impacts (CALS 2016, 2017). Thus, the institution gives meaning to what is perceived as mining companies' ethically correct actions. 
Table 5 Matching external social performance and its subcategories to SLP guidelines

\begin{tabular}{|l|l|l|}
\hline Category & Sub-categories & Social and Labour Plan (SLP) Guidelines \\
\hline $\begin{array}{l}\text { Linkage } \\
\text { development }\end{array}$ & $\begin{array}{l}\text { Contribution to } \\
\text { education } \\
\text { (ID12/ID11/ID9/ID8/ID3/ } \\
\text { ID2/FS6A/FS4/G2/C5/ } \\
\text { C6/C2/NGO5) }\end{array}$ & $\begin{array}{l}\text { Human Resources Development Programme Section 46 (b) } \\
\text { Companies provide skill development to workers and the } \\
\text { community. } \\
\text { Skills should be applicable within and outside of the mining sector. }\end{array}$ \\
\cline { 2 - 3 } & $\begin{array}{l}\text { Local sourcing } \\
\text { (ID12/ID10/ID9/ID8/ID6/ } \\
\text { ID5/ID4/ID2/ID1/FS4/ } \\
\text { C5A/C2/NGO4) }\end{array}$ & $\begin{array}{l}\text { Local Economic Development (LED) Programme Section 46 (c) } \\
\text { Procurement targets from historically disadvantaged, owned } \\
\text { companies (Mining Charter/BBBEE) }\end{array}$ \\
\cline { 2 - 3 } $\begin{array}{l}\text { Supplier/enterprise } \\
\text { development } \\
\text { ID8/ID7/ID6A\&B/ID4/ } \\
\text { ID3/C5/C2/FS3/G3/G2/ } \\
\text { G1/MU1) }\end{array}$ & $\begin{array}{l}\text { Local Economic Development (LED) Programme Section 46 (c) } \\
\text { Income-generating project: supporting and capacitating existing } \\
\text { local businesses or establishing new businesses. }\end{array}$ \\
\cline { 2 - 3 } $\begin{array}{l}\text { Contribution to } \\
\text { ifrastructure } \\
\text { (ID12/ID11/ID9/ID8/ } \\
\text { ID7/ID5/ID4/ID3/ID2/ } \\
\text { C5/C4/FS6B/FS4/MU1/ } \\
\text { NGO1A) }\end{array}$ & $\begin{array}{l}\text { Local Economic Development (LED) Programme Section 46 (c) } \\
\text { Infrastructure programmes: provide or upgrade existing } \\
\text { infrastructure and basic services. }\end{array}$ \\
\cline { 2 - 3 } $\begin{array}{l}\text { Financial provision } \\
\text { (ID12/ID9/ID8/ID4/ID2/ } \\
\text { C1/FS6B/FS2/G2) }\end{array}$ & $\begin{array}{l}\text { Financial Provision Section 46 (e) } \\
\text { Information about the implementation budget for the respective SLP. }\end{array}$ \\
\hline
\end{tabular}

The coding revealed a strong interface between SLPs as well as the deductively derived social performance sub-categories. The SLPs cover and even exceed all these sub-categories. On top of those, companies must conduct enterprise development ${ }^{2}$ by capacitating existing local businesses or establishing new ones. Furthermore, for the financial provision of the respective SLP, mining companies set up trusts and dedicate a share of their profit to communities via these (compare CALS 2016, 2017). Without enough upliftment measures available to communities through SLPs, it is not possible to mine in SA (ID12,11,8,7,2). ${ }^{3}$ Thus, “(...) there is always a social angle to mining" (ID11), and an SLP "pretty much dictates all social responsibility of the mine" (C4/GO2). In fact, all companies are obliged to conduct the outlined social performance measures (Table 5), and company respondents are aware that the government is not able to fulfil its full mandate for these services (ID9/GO4-3): "So, there is that dynamic as well in SA where something that would be traditionally considered as a government service is actually provided by the private sector" (ID9).

This finding confirms the prominent role of GOs in understanding how SA's mining sector functions-that is, the researched institutional field. SA's legal requirements in mining are perceived as beyond or at the level of international best practices (ID9/ID2/C6/C1). All interviewees essentially reported the existence of state actors' institutional enforcement (ID11-8, 5,2/C6,5,2,1/FS6B,4,2/G4-1/MU2-1/ NGO4-2). The interviewed key officials of the Department

\footnotetext{
$\overline{2}$ Inductively added sub-categories are additionally italicised.

${ }^{3}$ See methodology—-step three on acronyms. Multiple different acronyms indicate multiple evidences related to one finding or quote.
}

of Environmental Affairs (GO4), Department of Water \& Sanitation (GO3), Department of Mineral Resources (GO2) in the leading role and Department of Trade and Industry (GO1) were considered throughout the entire data sample as the most relevant GOs in the sector. Hence, the institutional void concept is not applicable to SA. However, it is necessary to dive deeper into the institution's enforcement to understand the related institutional uncertainty. State actors' institutional pressure was reported to be weakened by certain factors that are outlined in the following section.

\section{State Actors' Weakening Factors as Drivers of Institutional Uncertainty}

The national regulation and its coercive pressure along regulative institutions appear powerful. However, four weakening factors of GOs were reported to weaken the SLPs' institutionalisation and enforcement. The inductively identified weakening factors thus form drivers for the institutional uncertainty in the institutional field.

On a macro level, political (in-)certitude-see exploratory quotes in Table 6-was reported across the actor groups. Policy arbitrariness related to mining regulation in general as well as SLPs was evident (ID11-8,2/FS4,3,1/C5/ $\mathrm{GO} / \mathrm{NGO} 4,1 \mathrm{~b}$ ).

The lacking certitude is paired with regulatory compatibility-i.e. not well-suited regulation-in different forms. First, the regulation is characterised by generic conditions that are vague and therefore partially unenforceable (ID8/ GO4,2/NGO2). Furthermore, an ill-defined financial provision - an undefined amount of spending and investments' expected impact—as a key indicator for social performance does not guarantee meaningful social contributions (ID12,9/ 
Table 6 Weakening factors of state actors: sample quotes

\begin{tabular}{|c|c|c|}
\hline \multicolumn{2}{|r|}{ Weakening factors } & Quote \\
\hline \multirow{3}{*}{ 竞 } & Policy environment uncertain & $\begin{array}{l}\text { "The mining policy environment is still uncertain in this country and that } \\
\text { makes some international investors stay away" (ID11). }\end{array}$ \\
\hline & Mining rights withdrawal & $\begin{array}{l}\text { "SLPs introduce a huge amount of uncertainty about what mining } \\
\text { companies have to do and they can also get in trouble on their mining } \\
\text { rights if they fail to comply adequately with the SLPs" (NGO4). }\end{array}$ \\
\hline & Ease of doing business & $\begin{array}{l}\text { "Because of legislation, you would say mining companies are less } \\
\text { attracted to SA and they maybe go to weaker states in Africa, (...), let's } \\
\text { call it ease of doing business here" (GO1). }\end{array}$ \\
\hline \multirow{3}{*}{ 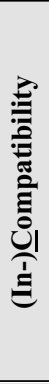 } & $\begin{array}{l}\text { Vague and unenforceable } \\
\text { regulation }\end{array}$ & $\begin{array}{l}\text { "What is being promised in these SLPs of the mining companies are more } \\
\text { often than not (approx. } 90 \% \text { ) these promises are not met because the law } \\
\text { is deliberately vague, (...), in fact, the law allows so many loopholes" } \\
\text { (NGO2). "If I look at some of those from Department of Mineral } \\
\text { Resources (GO2), there may be generic conditions inside, but nobody can } \\
\text { comply with or the condition is so irrelevant or vague or unenforceable" } \\
\text { (GO4). }\end{array}$ \\
\hline & Unsui & $\begin{array}{l}\text { "The SLP, the key indicators are 'have you spent money?' It's a rubbish } \\
\text { indicator and more impact-related indicators are needed" (ID12). }\end{array}$ \\
\hline & Compl & $\begin{array}{l}\text { "(...) There are often conflicts within a community, the accepted } \\
\text { traditional leader may be rejected within the community" (NGO4). }\end{array}$ \\
\hline \multirow{4}{*}{ 胥 } & $\begin{array}{r}\text { Poor regulato } \\
\text { che } \\
\text { (comp }\end{array}$ & $\begin{array}{l}\text { "You have to distinguish between legal requirements, possible offences, } \\
\text { and voluntary or market-related compliance. In terms of legal compliance } \\
\text { (...), I suspect that compliance is very - is poor" (GO4). "The major } \\
\text { weakness in SA is that the country got very good law, but very bad } \\
\text { political will, very weak political will, and very weak enforcement" } \\
\text { (NGO1B). }\end{array}$ \\
\hline & $\begin{array}{r}\text { Missing ski } \\
\text { (cor }\end{array}$ & $\begin{array}{l}\text { "There is a gap between the mining companies and the Department of } \\
\text { Mineral Resources (GO2), and it's that these guys are first world in their } \\
\text { application [mining companies] - (...) everything is of a world-class } \\
\text { standard. These guys [department] have not had that education, so you've } \\
\text { got an intellectual divide" (C4A). }\end{array}$ \\
\hline & $\begin{array}{l}\text { Underd } \\
\text { (State }\end{array}$ & $\begin{array}{l}\text { "(...) SLPs have a five-year life, okay, they're also very focused around } \\
\text { your communities, around your mine, and that's all very good (...). } \\
\text { However, you're not really resolving the problems of a region. You're } \\
\text { just resolving the problems of a few villages" (ID12). }\end{array}$ \\
\hline & $\begin{array}{l}\text { Missing infrastructural } \\
\text { delivery } \\
\text { (State actors'/GOs' delivery) }\end{array}$ & $\begin{array}{l}\text { "(...) There are dependencies that certain things need to be done by the } \\
\text { municipality first before the mine can do certain things. If there is a } \\
\text { weakness in the municipality in terms of not delivering on the } \\
\text { dependency, then the mine is not able to deliver" (ID5). }\end{array}$ \\
\hline \multirow{4}{*}{ | } & $\begin{array}{c}\text { Conflict of interest among } \\
\text { politicians }\end{array}$ & $\begin{array}{l}\text { "The government officials are so corrupt that rooting out corruption is } \\
\text { going to take us years to deal with" (NGO5). }\end{array}$ \\
\hline & Nepotism in ministry & $\begin{array}{l}\text { "The unfortunate thing is that the Department of Minerals (GO2) also } \\
\text { plays a very big role in how the mines operate (...). They are very } \\
\text { adamant that things are done right but then there's also nepotism etc. } \\
\text { because you have to have a mining license. So, they can make or break } \\
\text { you. (...) If you're not in line with what those guys require or if you don't } \\
\text { know them well enough (...)" (C5A). }\end{array}$ \\
\hline & Missing community money & $\begin{array}{l}\text { "(...) These communities should be one of the richest communities based } \\
\text { on their corporate social responsibility. It's been the worst because the } \\
\text { money is dissipating to somewhere and it's not benefiting the farm } \\
\text { workers, the local guys, the workers on the mine" (C4A). }\end{array}$ \\
\hline & Unequal wealth distribution & $\begin{array}{l}\text { "I think we learned }(\ldots) \text { from previous experience, so we work with the } \\
\text { royal family and community members to ensure the projects that we do } \\
\text { are for the benefit of the whole community" (ID8). }\end{array}$ \\
\hline
\end{tabular}

GOs' overall capacity regarding mining permits, SLPs' compliance checks and local development planning is questioned (ID8,7/C4,2/GO4/GO2/MU2). Since SLPs go hand in hand with underdeveloped local development plans, tailoring an appropriate SLP is difficult (MU1). Furthermore, municipalities do not deliver infrastructural components of SLPs and do not follow-up on components already delivered 
by mining companies to ensure their full implementation (ID12,5/GO3/NGO1A).

Corruption reflects another interrelated weakening factor. The current mining regulation is perceived to benefit a politically connected elite, thus potentially causing a conflict of interests (ID9/FS4/C4,1/MU2,1/NGO5,1A\&C). The local GOs' money from SLPs might drain away and fail to benefit the local population due to their lack of monitoring mechanisms (C5,4/MU2/NGO5,1 A\&B). Furthermore, according to some interviewees, $\mathrm{GO} 2$ as a state actor is too powerful and centralised and may consequently lead to nepotism (C5/ NGO1B). In addition, communities are incorporated to meet black ownership requirements (BBBEE); however, the mentioned tribal leader structures can cause problems because the wealth might not be adequately shared with the entire community or shares might be sold without consultation (ID8/NGO2).

In effect, the analysis of coercive sustainability pressure exerted by GOs reveals contradictory findings. On the one hand, the sound national regulation and its enforcement are respected among various actors of the institutional field, while on the other hand, GOs underlie the reported $\mathrm{C}^{4}$ weakening factors, which are certitude, compatibility, capacity and corruption. This leads us to our first proposition set $(\mathrm{P})$ :

Proposition 1 (P1): The four weakening factors-(in-) certitude, (in-)compatibility, (in-)capacity and corruptionlimit the adherence to an institution and thus create institutional uncertainty.

Proposition 1a (P1a): Missing certitude and compatibility limit the enforceability of a regulative institution and thus weaken the institution's institutionalisation process.

Proposition 1b (P1b): (In-)capacity and corruption weaken GOs' coercive pressure and thus limit enforcement that lowers the extent to which actors obey the institution.

These delicate constraints together weaken GOs' regulative institution itself and GOs' coercive pressure to enforce ethically perceived actions and thus drive institutional uncertainty; a topic that is discussed further in the next section.

\section{Institutional Uncertainty and Decoupling}

Referring to the conceptual section, the presented strive for legitimacy and resulting isomorphism cause conflicts of interest, and a decoupling from incorporated institutions might occur. Considering GOs' weakening factors-conceptualised as drivers for institutional uncertainty - there seems to exist a gap between mining companies' reported sustainability measures and what social performance mining-affected actors monitor (C4/NGO2,1A). This is also manifested in the accusation that some mining companies hide their SLPs and do not make them publicly available or only do so after legal measures are taken (FS6A,5/ NGO5,3,2,1B): "There is a disconnect between what the mines and the banks are telling their shareholders and investors and what is experienced in reality" (NGO2); "there's a difference between what the mines say and what's actually happening on the ground" (FS1). C4 elaborates on SLPs, asserting that "if you had to take exactly what's in the SLP and go look on the ground, would it match? $80-90 \%$ no" (C2).

Referring again to the GOs' weakening factors, reported SLPs' decoupling is assigned to the related compatibility, capacity and corruption to more thoroughly understand the consequences of institutional uncertainty in the institutional field. The vague political certitude remained largely implicit in the interviews, although it basically affects all actions in the field because the certitude missing from regulation questions the future value of companies' capital-intensive investments and long-term social performance projects (ID11-8/ FS4, 1/C5/GO2/NGO4).

Regulatory compatibility as a driver of mining companies' institutional uncertainty and decoupling/non-compliance are intertwined. The findings reveal that regulative ambitions can diverge from reality and lead to regulation-decoupling. Furthermore, mining companies often struggle to fully comply with vaguely regulative requirements. This vagueness leaves room for differing interpretations of companies' compliance in the SLP projects and thus allows for a certain level of decoupling (ID12,9,8,3,2/C5,4,2/FS6B,4,1/GO2/NGO2,1). Tables 7,8 and 9 provide examples for the aggregated findings of each weakening factor and decoupling.

GOs' capacities to monitor and coerce compliance as another driver of institutional uncertainty and decoupling are interwoven. Due to GOs' capacity shortages regarding enforcement, as all details of the SLP's full implementation simply cannot be investigated, and lacking GOs' SLP delivery due to budgetary limitations, further opportunisticdecoupling leeway is provided (Table 8), and social performance implementation is reduced (ID9,8,5,3/C5/GO3,1/ NGO4,3,1A\&B/MU1).

Corruption and mining companies' relations with GOs or the community's accepted representatives might reduce the sanctions of lacking compliance and thus increase the freedom for bribe-decoupling (Table 9) in the sense that investigations and compliance enforcements are not conducted at all or not fully (ID3/C5/GO3/NGO5,1A\&B). In addition, the company size and likelihood to decouple are related; smaller mining companies face greater difficulty in 
Table 7 Evidences and samples of regulation-decoupling caused by the institutional uncertainty driver compatibility

\section{Companies' compliance struggles with regulation}

- Compatibility problems are evidenced when companies decouple due to regulative requirements that cannot be met (ID9,8,2/FS6B,4/GO2).

Sample: "(...) The regulation and reality differ. If it's mandatory to spend $\mathrm{x} \%$ of the procurement budget for black female-owned businesses and those are not existent, then you can't spend the money" (ID2). GO2 requires supplier development in such instances, which is difficult since women in rural areas rarely own a business (ID2/F6B/FS4).

Differing compliance interpretations

- Due to vaguely regulative requirements that do not give precise guidance on how to perform socially, companies might select wrong management approaches (ID12,9,3/FS4,1/NGO2,1).

Sample: ID12 admits wrong management approaches for resettlement and the integral housing component (Table 5 - contribution to infrastructure): “(...) I'm honest with you (...), what tended to happen is we had project managers leading resettlement and they don't understand resettlement (...)."

Table 8 Evidences and samples of opportunistic-decoupling caused by the institutional uncertainty driver capacity
Table 9 Evidences and samples of bribe-decoupling caused by the institutional uncertainty driver corruption

\begin{abstract}
- Regulatory control perceived by companies
Weak capacity of state actors is manifested in the perceived compliance checks of companies and can enable leeway (ID9,8,3/C5/GO1).

Sample: Related to social delivery, ID9 states: "No, you don't have to be $100 \%$ compliant (...)." Furthermore, the mining company states never being sanctioned before: "But you will find certain areas where you can always do more."

- Company practices that differ from outcomes intended by regulation

Companies practices might differ from regulatory intentions due to the existent leeway and/or due to not delivered social measures of state actors (ID9,5/C5/GO3,1/NGO4,3,1A\&B/MU1).

Sample: "So, what we found was this huge gap between what these corporations were saying about themselves and what their actual practices were" (NGO1A).
\end{abstract}

complying due to resources and might be more prone to small-scale corruption (ID8,6/C4).

The above findings lead to the next proposition set:

Proposition 2 (P2): Institutional uncertainty allows for companies' gradual decoupling from institutions, which hinders the creation of social sustainability.

Proposition 2a (P2a): Regulation-decoupling due to missing compatibility is manifested in as unfulfillable perceived requirements or missing specifications of institutions.

Proposition 2b (P2b): Opportunistic-decoupling because of (in-)capacity is evidenced by social practices that diverge from the institution's intentions due to missing state actors' coercion and social measures.

Proposition 2c (P2c): Bribe-decoupling due to corruption is a company size-dependent outcome of companies' corruption attempts and prone state actors.

The findings of reported decoupling demonstrate that these occurrences are not merely the result of mining companies' actions in response to outside pressure that causes a conflict of interest. Weakened GOs with reduced coercive pressure and existing institutional uncertainty play their part in creating SLP non-compliance leeway in the institutional 
field, as both are intertwined and might be mutually dependent. This results in companies failing to provide the full social performance that is expected of them. However, companies with their "false sense of legitimacy" nevertheless face a "crisis of legitimacy" because they are hindered by unethically perceived actions and officially reported isomorphism (NGO5,1A). We label these impeding interactions as the complementing pressures that are presented in the next section.

\section{Complementing Pressures as Barriers to Institutional Uncertainty}

All actors referenced the SLPs as their main institution for scrutinising and consequently pressuring mining companies for more social sustainability in the field. The interviewed actors reported a wide variety of interactions that pressured companies to meet ethical expectations and debilitate the identified state actors' weakening factors and decoupling thereof. The analysis revealed 23 individual interactions both within and among the actor groups, and propositions lists the interactions by the individual actor groups leading to aggregated coercive, mimetic and normative pressures. These pressures complement the weakened GOs, and according to Tracey and Phillips (2011), they can be perceived as barriers to institutional uncertainty in the field because they raise the legitimacy cost of not implementing certain institutions. Thus, these pressures are necessary to obtain a full understanding of how social sustainability is established.

The interviewees in this study described a vibrant actor scene. As shown in Table 5, SA's mining regulation adds weight to the communities that interact among one another and with both NGOs and unions to join forces. Mine workers represented by MUs often live in surrounding communities, and Table 10 illustrates that communities collaborate with
Table 10 Sustainability interactions leading to complementing institutional pressures that are barriers to institutional uncertainty

\begin{tabular}{|c|c|c|c|}
\hline Pressure & Actor group & Identified interactions and interrelations & $\begin{array}{c}\text { Targeted } \\
\text { weakening } \\
\text { factors }\end{array}$ \\
\hline \multirow{5}{*}{ 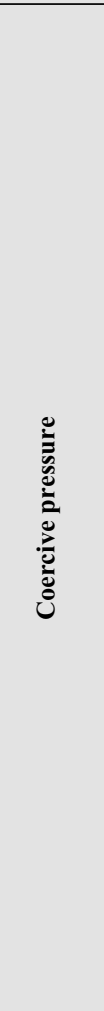 } & NGOs & $\begin{array}{l}\text { 1. NGOs collaborate globally and reach out to buyers internationally } \\
\text { (NGO1A,B\&C). } \\
\text { 2. NGOs collaborate locally to join forces (ID12/NGO5-1). } \\
\text { 3. NGOs publish reports about negative impacts and undelivered SLPs } \\
\text { (ID12,3/NGO5,3,1A\&C). } \\
\text { 4. NGOs create negative publicity via the media (ID9/NGO4,1A\&B). } \\
\text { 5. NGOs participate in legally prescribed forums and empower } \\
\text { communities through capacity building } \\
\text { (ID9,5,3/GO4,3/FS6A,5/NGO5,3-1A,B\&C). }\end{array}$ & \multirow{5}{*}{ 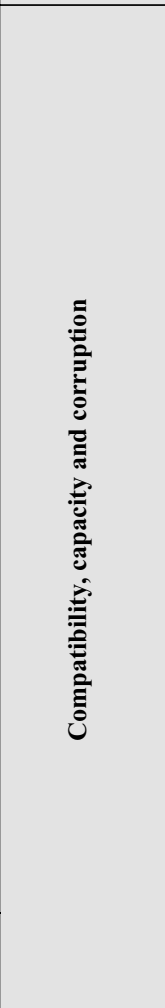 } \\
\hline & Communities & $\begin{array}{l}\text { 6. Communities join forces with other communities and NGOs } \\
\text { (ID12,9,5-3/NGO5,3-1\&B/MU2). } \\
\text { 7. Communities protest and stop operations } \\
\text { (ID10,7,5,2/C4,2,1/FS5/NGO1A). } \\
\text { 8. Communities participate in legally prescribed forums (ID9,3/C5/GO2). } \\
\text { 9. Communities are linked to mining unions via their inhabitants } \\
\text { (ID3,1/C5/NGO2/MU2). }\end{array}$ & \\
\hline & $\begin{array}{l}\text { Mining } \\
\text { unions } \\
\text { (MUs) }\end{array}$ & $\begin{array}{l}\text { 10. MUs monitor companies and SLPs delivery (ID5,1/GO2/MU2,1). } \\
\text { 11. MUs enforce strikes and operation stoppages (ID10-8,5/ID2,1/C3,1). } \\
\text { 12. MU, GO, and ID representatives engage in prescribed forums } \\
\text { (ID5/C5/GO4,2/MU2). }\end{array}$ & \\
\hline & $\begin{array}{c}\text { Financial } \\
\text { sector (FS) }\end{array}$ & $\begin{array}{l}\text { 13. FSs actively seek sustainability information from the industry and } \\
\text { NGOs (ID12,8,3/FS2/NGO1B). } \\
\text { 14. FSs try to mitigate risks: regulations, standards/guidelines, and } \\
\text { compliance (ID10,8,6,5/C4,1/FS6A\&B,5,3-1/GO3). } \\
\text { 15. FSs/state banks offer jointly development finance with high } \\
\text { sustainability requirements (ID5/C3-1/FS6A\&B,3-1). } \\
\text { 16. Shareholder activism via NGOs (ID4,3/GO4/NGO1B\&C). }\end{array}$ & \\
\hline & Buyers & $\begin{array}{l}\text { 17. Pressure from external regulations (ID11,6,5,3/C1/GO4/MU1). } \\
\text { 18. Buyers' upstream and downstream enforcements } \\
\text { (ID12,9,3,1/C6,5/FS4/GO4,2/NGO3,1B\&C). }\end{array}$ & \\
\hline \multicolumn{2}{|c|}{ Mimetic pressure } & $\begin{array}{l}\text { 19. Identified frontrunners ID12,ID9,ID6, and ID4 lead in sustainability } \\
\text { and inspire (ID5/C5/FS6A,4,1/MU1/NGO5,1A). } \\
\text { 20. Lessons learned from past wrongdoings enforce mimicry (ID12,8,5). }\end{array}$ & Compatibility \\
\hline \multicolumn{2}{|c|}{ Normative pressure } & $\begin{array}{l}\text { 21. Mining industry association (ID12,9,7,6,3/C4,1/FS3/GO4 } \\
\text { 1/MU2,1/NGO4,1A\&B) shares experiences among companies } \\
\text { (ID9,7,5/C5). } \\
\text { 22. Mining association develops its own regulating instruments to gain } \\
\text { market access and facilitate state audits (ID } 9,7,5,3 / \mathrm{C} 5 / \mathrm{C} 1 \text { ). } \\
\text { 23. Employees change companies (ID8,5/C5). }\end{array}$ & $\begin{array}{c}\text { Compatibility } \\
\& \\
\text { capacity }\end{array}$ \\
\hline
\end{tabular}


NGOs via capacity building to convey their rights and to monitor mining companies (interaction 5 of Table 10). MUs and communities are the main rights bearers under the SLPs for obtaining developmental benefits from mining (ID3,1/ $\mathrm{C} 5 / \mathrm{NGO} 2 / \mathrm{MU} 2)$. Aside from the fact that NGOs, with their affiliated communities and MUs, reach out to buyers globally by, for instance, visiting shareholder conferences and confronting downstream buyers (interactions $1,16,18$ ), they are also contacted by FSs that seek sustainability information (interaction 13). Furthermore, the financial sector (interaction 14) considers the risks of communities' (interactions 6,7 ) and MUs' (interaction 11) upheavals, and both are considered powerful pressure-exerting actors with legislative scope. In effect, actors interact with one another and share their expertise, media attention and legal voices to achieve enhanced conditions for the local population. Specifically, NGOs and MUs aim to support the communities through SLPs' implementation and enforcement by contributing their expertise and insights.

Moreover, and as indicated above, the interviewees reported that FSs and private sector buyers at the downstream SC create a sustainability leverage effect due to their demand. They enforce compliance with either the regulations from both SA and mineral importing countries or international standards and guidelines (e.g. ISO Standards, UN Global Compact and IFC Performance Standards) (interactions $13,14,17,18)$. However, the mentioned buyers are not necessarily located abroad; SA possesses local beneficiation facilities and a market where buyers also demand sustainability compliance (ID9, 6, 5).

With reference to the identified weakening factors/institutional uncertainty and the associated consequences regarding social performance, the evident coercive pressure can be regarded as limiting regulatory compatibility, the weak capacity and corruption vulnerability. The variety of interactions and their interrelations regarded together constitute a barrier to institutional uncertainty.

After outlining the coercive pressure in the institutional field, sustainability leaders in the mining sector, such as ID12, ID9, ID4 and ID6, are a source of inspiration regarding their best practices, leading to mimetic pressure (interaction 19). Isomorphic responses of frontrunners that exceed institutional rules are identified. They range from an adopted system perspective post-mining operation to stimulate socioeconomic development, over voluntary financial provisions beyond SLPs, to the measured impact against the integrated reports' six capitals and an appointed position for sustainability in SCs (ID12/ID9/ID6) (compare Jain et al. 2017similar mimetic pressure). Furthermore, the interviewees underlined that past wrongdoings in the sustainability domain helped them evolve toward greater sustainability (interaction 20). This finding reveals that the institutional pressure reflects a barrier to institutional uncertainty by directing its force against regulatory compatibility with companies that elaborate upon the prescribed social performance beyond ethical expectations.

In order to address normative pressure's verification difficulty (DiMaggio and Powell 1983), this case study includes a representative body of mining companies. It presents common and shared beliefs about conditions as well as work methods for greater legitimacy; all nine interviewed mining companies are members of this association (ID12,9-6,3/ $\mathrm{C} 4,1 / \mathrm{FS} 3 / \mathrm{GO} 4-1 / \mathrm{MU} 2,1 / \mathrm{NGO} 4,1 \mathrm{~A} \& \mathrm{~B})$. First, normative pressure stems from the fact that mining companies' sustainability managers interact with one another and GOs on a regular basis to share experiences (interaction 21). Second, the representative body incentivises its members to adopt their own developed and international standards to support GOs' regulations (interaction 22). Third, the change in professionals among the organisations in the field spread normative convictions (interaction 23). Taken together, this pressure is a barrier to institutional uncertainty because it targets regulatory compatibility through additional standards that increase legitimacy. The exchange of sustainability practices among companies and normative convictions among companies is helpful for this process and simultaneously limits weak capacity.

Another finding of this case study is that the pressures are interlinked; related to the previously mentioned normative pressure and the associations' members (interactions 21, 22), interrelations can be named among the coercive pressure created by the financial sector as well as buyers. These complementing interactions $(14,17,18)$ can be namely perceived as a motivation for mining companies to adopt sustainability standards. Moreover, the interactions among communities, MUs, NGOs, buyers and FSs constitute further evidence for interlinkages. As another interlink, the mentioned sustainability frontrunners exerting mimetic pressure are naturally exposed to all identified pressure sources.

These findings demonstrate that it is vital for social sustainability in SCs to understand state and non-state actors that constitute the institutional field and play a vital role in ensuring social sustainability. The interactions and interrelations that build up to interlinked coercive, mimetic and normative pressures are grounded in the national context and enforce ethical practices, which leads us to the third set of propositions.

Proposition 3 (P3): Interactions among actors create interlinked coercive, mimetic and normative institutional pressures that complement weakened state actors and thus limit institutional uncertainty with its negative effects on social sustainability.

Proposition 3a (P3a): Field actors' coercive pressure limits the weakening factors compatibility, capacity and corruption by self-reinforcing interactions to warrant compliance with 
the regulative institution and warrant development benefits for the institution's main right bearers.

Proposition 3b (P3b): Field actors' mimetic pressure limits the weakening factor compatibility by providing cases that might inspire other companies to mimic.

Proposition 3b (P3c): Field actors' normative pressure limits the weakening factor compatibility and capacity by promoting practices through normative convictions.

\section{Resulting Empirical Analysis-Based Framework}

Figure 2 visualises our chain of thoughts presented above. The GOs/state actors and their social institution (SLPs) are-despite the afore-mentioned weakening factors-the most influential actor group that coerces compliance by companies. As highlighted throughout the paper, the prime regulative institution with respect to companies' social performance delivery is the study's focus. However, four weakening factors as drivers of institutional uncertainty were identified in the interview material and were thus inductively added (Proposition 1, P1a and P1b). Hence, despite the external pressure to comply with extensive social performance (i.e. ethical practices), companies decouple due to the existing institutional uncertainty through the weakly entrenched social sustainability institution and do not deliver the full social sustainability (P2, P2a, P2b and P2c).

The study additionally identifies barriers to the creation of institutional uncertainty (P3). On one hand, the nonprofit-orientated actors and their interrelations complement GOs, coerce compliance with the institution and request that the expected ethical actions are fulfilled through their various interactions (Table 10). On the other hand, and aside from their economic orientation, interrelated for-profit actors complement and coerce further and check companies' compliance with regulation (P3a). Moreover, the mimetic pressure $(\mathrm{P} 3 \mathrm{~b})$ and normative pressure $(\mathrm{P} 3 \mathrm{c})$ contribute toward the adoption of social sustainability within the industry and limit institutional uncertainty. Consequently, companies report on sustainability and operate within the state regulations, including the existent decoupling leeway due to institutional uncertainty that is manifested in reduced social sustainability (P2, P2a, P2b and P2c).

\section{Discussion}

The evident wealth of minerals in EMDE and the prominent role of the extractive industry in terms of country development can be evidenced in many regions (Sauer and Seuring 2019; Mayes 2015; Giurco and Cooper 2012). This case study is an example of the extractive industry's relatively good governance that contrasts the currently predominant

Institutional uncertainty and decoupling: Drivers, barriers and their effect on social sustainability

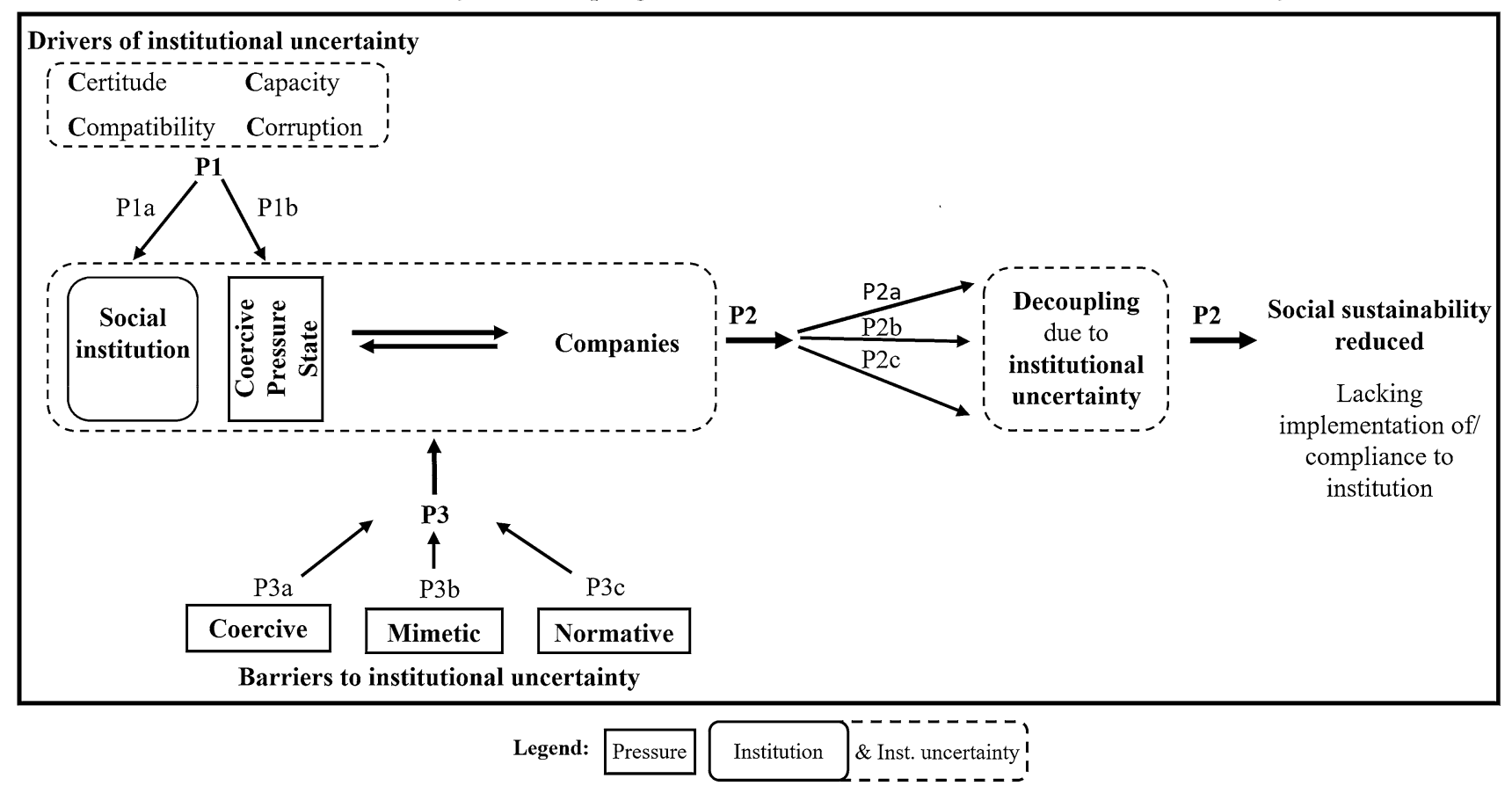

Fig. 2 Deconstructing social sustainability enforcement and the role of institutional uncertainty 
research focuses on failed states and institutional voids (Hofmann et al. 2018; Huq and Stevenson 2018; Jain et al. 2017; Silvestre 2015). In comparison to environmental and safety measures, social sustainability - such as the provision of societal services like housing-remains underdeveloped and offers companies improvement opportunities (Hamann and Bertels 2018). This lack of social considerations falls in line with the initially mentioned research on sustainability in global SCs, which has been found to focus on environmental sustainability and being "Western-based" (Golicic et al. 2019, p. 14; Huq and Stevenson 2018; Yawar and Seuring 2017; Quarshie et al. 2016). This study addresses empirical quests by underlining the relevance of unconventional SC members to enable social impacts and deal with the complexity of EMDE (Golicic et al. 2019; Quarshie et al. 2016; Hall and Matos 2010).

By placing institutional uncertainty and neglected decoupling outcomes at its research core before adding new layers, the extant study addresses criticism of institutional theory (Huq and Stevenson 2018; Wilhelm et al. 2016; Boxenbaum and Jonsson 2013). Hence, we aim to enrich the discussion focused on enhancing social sustainability in (commodity) SCs by empirically unravelling institutional uncertainty alongside its drivers and barriers (Huq and Stevenson 2018; Tracey and Phillips 2011). This careful analysis of institutionalisation in the field-represented by one SC tier-is necessary for examining the decoupling phenomenon that is driven by institutional uncertainty (Bromley and Powell 2012; Tracey and Phillips 2011). Moreover, the exclusive focus on the SC's first-tier and its institutional environment rather than an investigation of buyer-supplier relationships yielded important insights for understanding how sustainability's institutionalisation is enabled and undermined and thus how it ultimately affects the sustainability downstream (Golicic et al. 2019). Our theorised weakening factors elaborate upon Huq and Stevenson's (2018) governmental coercive pressure and add new layers of detail. On the one hand, the carved out weakening factors can be perceived as evidence that companies "are simply not able to perfectly replicate an institutionally sanctioned structure or practice" (Boxenbaum and Jonsson 2013, p. 85); on the other hand, the decoupling magnitude from institutionalised regulative elements is the result of mining companies' adherence to weakened state actors' regulative institution. Both are harmful regarding the fulfilment of societal expectations, which depends on institutions' correct and context-dependent enforcement (Huq and Stevenson 2018; Jain et al. 2017; Wilhelm et al. 2016), and thus constitutes an ethical issue relevant at the local and SC levels that leads to reputational risks downstream (Sauer and Seuring 2019; Hofmann et al. 2018; Busse et al. 2016b).

Furthermore, the emphasised complementing pressures (Table 10) and the level of existing institutional pressures must be considered for one to understand the degree of institutional uncertainty in an institutional field and resulting sustainability practices. The institution fuels the ethical expectations of the complementing pressures that present barriers to institutional uncertainty. Thus, the sustainability institution is in contrast to other EMDE contexts, such as mining in India, of great relevancy in SA (Jain et al. 2017). Hence, the exclusive focus on a regulative institution contributes toward identifying barriers that help the respective institution, ideally without decoupling, achieve its goals (Wijen 2014). These barriers cover coercive, mimetic and normative pressures and are differentiated by interactions in the field because they are not one homogenous form of pressure. To understand the institutional field's functioning in greater depth, pressure interrelations and interlinks are delineated to aid the understanding of the pressure dynamic in the institutional field (Jain et al. 2017; Wooten and Hoffman, 2013). It may be argued that the complementing pressures do not exclusively complement weakened GOs and their coercive pressure, but also complement one another or re-enforce themselves. Hence, it is essential that the interrelations and interlinks are analysed to understand their characteristics more deeply. This in-depth investigation falls in line with calls for a more specified use of institutional theory and (social) sustainability/ethics in SCs (Golicic et al. 2019; Amis et al. 2018; Yawar and Kauppi 2018; Quarshie et al. 2016). Therefore, the thus far often neglected institutional pressure's origins, characteristics, interrelations and influence can be understood in greater depth (Kauppi 2013).

The findings of this study evidence that non-state companies' structures and practices are shaped by complex interactions in the field with its respective context and history as put forward by Scott (1997) (see also Huq and Stevenson 2018; Wilhelm et al. 2016). We found that within this complex interacting of multiple pressures non-state actors are equipped with means to confront institutional uncertainty with its consequences on companies' compliance leeway (Jain et al. 2017; Simpson et al. 2012; Hafner-Burton and Tsutsui 2005). Hence, this study suggests that the investigated actors (stakeholders) are not powerless in the EMDE country, which contrasts the literature on (mineral) SCs (Huq and Stevenson 2018; Sauer and Seuring 2017; Quastel 2011). As the ultimate suppliers, mining companies in SA appear to be exposed to similar institutional pressures as focal companies at the downstream part, namely non-state actors, GOs and customers. Thus, the study addresses the current lack of empirical investigations beyond the buyer-supplier relations and downstream-oriented SC research with the captured ethic perspectives of diverse upstream actors (Golicic et al. 2019; Huq and Stevenson 2018; Quarshie et al. 2016; Pagell and Shevchenko 2014). In the debate on ethics in global sourcing and SCs, only minor attention has been paid to state and non-state actors on the supply side as well as how they exert institutional pressures to enhance 
social sustainability (Huq and Stevenson 2018; Jain et al. 2017; Quarshie et al. 2016; Vermeulen 2013).

Moreover, these findings offer evidence for the predicted consideration of institutions and pressures that are non-efficiency and non-profit orientated (Bromley and Powell 2012; Meyer and Rowan 1977). Therefore, managers do not only follow economic efficiency paradigms and they are influenced by external sustainability pressures (Kauppi 2013); this point raises the managerial implications introduced in the next section.

\section{Managerial Implications}

Since theory offers practical guidance, situations and circumstances to which the SA findings can be applied are examined (Van de Ven 1989; Lewin 1943). By applying institutional uncertainty and institutional theory to frame the (non-conventional upstream) actors, new insights can be drawn as to how first-tier SC companies, alias (sub-) suppliers, are influenced in an institutional field (Quarshie et al. 2016; Busse et al. 2016b). The findings reveal that sustainability impacts and their interpretation - up to the initial SC stage in an EMDE context-are not merely a result of SC managers' endeavours at the downstream SC; the identified institutional uncertainty and differentiated pressures might enhance the understanding of the upstream SC and the respective institutional field. Therefore, the theoretical lens provides guidance in complex contexts and might help tailor appropriate (social) sustainability measures to complement firms' broader sustainable supply chain management strategies (Golicic et al. 2019; Quarshie et al. 2016). The identified specific practices (Table 5)—within the underresearched SLPs (CALS 2016, 2017)—can serve practitioners as an orientation regarding possible paths to enhance corporate (social) sustainability and enable a meaningful contribution to the UN SDGs 4, 8, 10, 11, 12 and 16 (ICMM 2018). Furthermore, applying this case study's theoretical framing and shedding light on the societal realities at the extraction stage might help sustainability change-agents in firms for arguing to crack open the pure price consideration of the conventional mineral SCs (Sauer and Seuring 2019; Pagell and Wu 2009).

To manage institutional uncertainty, practitioners might consider the usage of a complementary standard to a regulative institution in an EMDE context that supports the respective institution's institutionalisation. Hence, the other way around (Jain et al. 2017), a soft-law might elaborate on already existing and established (social) institutions in a specific EMDE context without institutional voids, but institutional uncertainty. Moreover, a bottom-up approach that seeks collaborations with a variety of physically present upstream actors (e.g. communities including tribal structures, NGOs and MUs) might be essential for a standard's impact (see also Golicic et al. 2019, Quarshie et al. 2016; Simpson et al. 2012), since it enables a greater understanding of current shortcomings of the legislative set-up (i.e. institutional uncertainty, decoupling). In addition, interactions and interrelations (Table 10) help to understand what is already accomplished by the different existing pressure groups. Furthermore, for financial mechanisms that offset negative impacts at the upstream SC, company size-dependent monitoring mechanisms for the capital streams are required to avoid the nurturing of corrupt structures. Institutional theory can help to frame all this, spot synergy potentials to intensify coordination as well as cooperation with and among pressure groups and ultimately combat reputational risk or even create a market for ethically sourced mineral commodities.

\section{Limitations and Future Research Directions}

We acknowledge that the construct validity might be reduced because interviews cannot prevent some scope of bias (Yin 2014) and content analysis naturally induces some bias via the individual "world view" (Kuckartz 2016; Mayring 2015), yet we strived for limiting this bias to a minimum (see Table 4). Regarding internal validity, the delineated relationships and pressure dynamic in the institutional field are time-space dependent. Referring to reliability, an identical replication of the conducted research is difficult to procure due to the institutional field's complexity, the resulting coincidence and the researchers' and interviewees' characteristics. Regarding external validity, the preceding discussion and managerial implications show the generalisation and consider the existent degree of context dependency.

Aside from the data sample's strength drawn from its diverse set of interviewed actors, all mining companies are first of considerable size and capital strength, and second are formally registered. These characteristics limit the study's external validity since artisanal and small-scale mining are relevant on the African continent (Fold et al. 2014; Bloch and Owusu 2012), thus calling for further research that includes informal mining.

SA, alongside its history and the resulting mining regulation with its SLPs, shape the institutional field. Hence, comparative upstream data from another field can enhance the understanding of specific contextual factors, institutional infrastructure (e.g. actors and regulation) and sustainability outcomes. A cross-case analysis and synthesis of the current study's findings with a comparable embedded case study could enhance internal and external validity.

Another future research topic may be the role of cognitive, cultural, informal structures and norms as external institutions that remain untouched in this study (Busse et al. 2016b; Phillips et al. 2009; DiMaggio and Powell 1983). A topic that does not fall within this study's scope and has not been determined evident in this research field is the external pressure of FSs and buyers as for-profit actors, for which mining companies' profits and shareholder value are concerns (see also Sauer and Seuring 2019; Jain et al. 2017; Young 2015). Thus, the consequences of global efficiency logics on the social 
performance outcome in a corresponding institutional field merit a separate future analysis (Huq and Stevenson 2018).

Aside from institutions' role in promoting sustainable practices, Sarkis et al. (2011) as well as Bromley and Powell (2012) call for an investigation into internal and external processes. This study sheds light on the external drivers and barriers, but the internal perspective remains outside its scope. The internal micro-level processes for the adoption of sustainability practices and reduced decoupling in a rather well-governed institutional field with institutional uncertainty thus remain an open research trajectory (Powell and Rerup 2017). Our suggestions, may serve as fruitful starting points for further analysis into actors' interactions and their ethical responses.

\section{Conclusion}

This case study seeks to reach beyond the current literature on social sustainability in SCs and EMDE contexts. As our theoretical contribution, we unearthed the importance of institutional uncertainty with its drivers and barriers at the upstream stages of a (mineral) SC.

Specifically, the study found at least three components composing the bedrock for establishing social sustainability in mining: (1) the regulative framework and its state enforcement that is affected by four identified weakening factors - (in-)certitude, (in-)compatibility, (in-)capacity and corruption-as drivers of institutional uncertainty, (2) mining companies' (non-) responses - theorised as decoupling - to the institutional field's pressures and (3) the interplay of the non-state actors in the sector that complement the weakened state actors and constitute barriers to institutional uncertainty through coercive, mimetic and normative pressures.

Therefore, institutional uncertainty, due to its hampering effect on ethical practices, requires careful consideration when striving for realisation of the full (social) sustainability potential in a SC.

Acknowledgments Open Access funding is generously provided by the German "DEAL" agreement. We thank Springer Nature and Max Planck Digital Library Services GmbH.

This research was conducted as part of the "NamiRo" research project on sustainably-produced minerals. It was financially supported by the German Federal Ministry of Education and Research (BMBF) (Grant No. 01UT140).

The data collection by Nikolas Kelling in South Africa was supported by a research grant under the DAAD programme exceed - Higher Education Excellence in Development Cooperation of the International Center for Development and Decent Work (Grant No. 57160015).

\section{Compliance with Ethical Standards}

Conflict of interest The authors declare that they have no conflicts of interest.

Open Access This article is licensed under a Creative Commons Attribution 4.0 International License, which permits use, sharing, adaptation, distribution and reproduction in any medium or format, as long as you give appropriate credit to the original author(s) and the source, provide a link to the Creative Commons licence, and indicate if changes were made. The images or other third party material in this article are included in the article's Creative Commons licence, unless indicated otherwise in a credit line to the material. If material is not included in the article's Creative Commons licence and your intended use is not permitted by statutory regulation or exceeds the permitted use, you will need to obtain permission directly from the copyright holder. To view a copy of this licence, visit http://creativecommons.org/licenses/by/4.0/.

\section{References}

Amis, J. M., Munir, K. A., Lawrence, T. B., Hirsch, P., \& McGahan, A. (2018). Inequality, institutions and organizations. Organization Studies, 39, 1131-1152. https://doi.org/10.1177/0170840618 792596.

Arya, B., \& Bassi, B. (2011). Corporate social responsibility and broad-based Black Economic Empowerment Legislation in South Africa: Codes of good practice. Business \& Society, 50, 674-695. https://doi.org/10.1177/0007650309332261.

Bloch, R., \& Owusu, G. (2012). Linkages in Ghana's gold mining industry: Challenging the enclave thesis. Resources Policy, 37, 434-442. https://doi.org/10.1016/j.resourpol.2012.06.004.

Blome, C., \& Paulraj, A. (2013). Ethical climate and purchasing social responsibility: A benevolence focus. Journal of Business Ethics, 116, 567-585. https://doi.org/10.1007/s10551-012-1481-5.

Boxenbaum, E., \& Jonsson, S. (2013). Isomorphism, Diffusion and Decoupling. In R. Greenwood, C. Oliver, R. Suddaby, \& K. Sahlin-Andersson (Eds.), The SAGE Handbook of Organizational (pp. 78-98). London: Sage.

Bromley, P., \& Powell, W. (2012). From smoke and mirrors to walking the talk: Decoupling in the contemporary world. The Academy of Management Annals, 6, 483-530. https://doi.org/10.1080/19416 520.2012 .684462$.

Bryman, A., \& Bell, E. (2011). Business research methods (3rd ed.). Oxford: Oxford University Press.

Busse, C., Schleper, M. C., Niu, M., \& Wagner, S. M. (2016a). Supplier development for sustainability: Contextual barriers in global supply chains. International Journal of Physical Distribution \& Logistics Management, 46, 442-468. https://doi.org/10.1108/ IJPDLM-12-2015-0300.

Busse, C., Kach, A. P., \& Bode, C. (2016b). Sustainability and the false sense of legitimacy: How institutional distance augments risk in global supply chains. Journal of Business Logistics, 37, 312-328. https://doi.org/10.1111/jbl.12143.

CALS. (2016). The Social and Labour Plan Series: Phase 1: System Design. Trends Analysis Report. Centre for Applied Legal Studies. University of Witwatersrand : Open Society Foundation for SA.

CALS. (2017). The Social and Labour Plan Series: Phase 2: Implementation. Operation Analysis Report. Centre for Applied Legal Studies. University of Witwatersrand: Open Society Foundation for SA.

Clarke, A., \& Crane, A. (2018). Cross-sector partnerships for systemic change: Systematized literature review and agenda for further 
research. Journal of Business Ethics, 150, 303-313. https://doi. org/10.1007/s10551-018-3922-2.

DiMaggio, P. J., \& Powell, W. W. (1983). The iron cage revisited: Institutional isomorphism and collective rationality in organizational fields. American Sociological Review, 48(2), 147-160.

Dubois, A., \& Gadde, L. (2002). Systematic combining: An abductive approach to case research. Journal of Business Research, 55, 553-560. https://doi.org/10.1016/S0148-2963(00)00195-8.

Ehrgott, M., Reimann, F., Kaufmann, L., \& Carter, C. R. (2011). Social sustainability in selecting emerging economy suppliers. Journal of Business Ethics, 98, 99-119. https://doi.org/10.1007/s1055 1-010-0537-7.

Eisenhardt, K. M., Graebner, M. E., \& Sonenshein, S. (2016). Grand challenges and inductive methods: Rigor without rigor mortis. Academy of Management Journal, 59, 1113-1123. https://doi. org/10.5465/amj.2016.4004.

Fessehaie, J., \& Morris, M. (2013). Value chain dynamics of Chinese copper mining in Zambia: Enclave or linkage development? European Journal of Development Research, 25, 537-556. https://doi. org/10.1057/ejdr.2013.21.

Fold, N., Jønsson, J. B., \& Yankson, P. (2014). Buying into formalization?: State institutions and interlocked markets in African smallscale gold mining. Futures, 62, 128-139. https://doi.org/10.1016/j. futures.2013.09.002.

Franks, D. D., \& Vanclay, F. (2013). Social Impact Management Plans: Innovation in corporate and public policy. Environmental Impact Assessment Review, 43, 40-48. https://doi.org/10.1016/j. eiar.2013.05.004.

Gioia, D. A., Corley, K. G., \& Hamilton, A. L. (2013). Seeking qualitative rigor in inductive research. Organizational Research Methods, 16, 15-31. https://doi.org/10.1177/1094428112452151.

Giurco, D., \& Cooper, C. (2012). Mining and sustainability: Asking the right questions. Minerals Engineering, 29, 3-12. https://doi. org/10.1016/j.mineng.2012.01.006.

Golicic, S. L., Lenk, M. M., \& Hazen, B. T. (2019). A global meaning of supply chain social sustainability. Production Planning \& Control, 28, 1-17. https://doi.org/10.1080/09537287.2019.1695911.

Hafner-Burton, E., \& Tsutsui, K. (2005). Human rights in a globalizing world: The paradox of empty promises. American Journal of Sociology, 110(5), 1373-1411.

Hall, J., \& Matos, S. (2010). Incorporating impoverished communities in sustainable supply chains. International Journal of Physical Distribution \& Logistics Management, 40, 124-147. https://doi. org/10.1108/09600031011020368.

Hamann, R., \& Bertels, S. (2018). The institutional work of exploitation: Employers' work to create and perpetuate inequality. Journal of Management Studies, 55, 394-423. https://doi.org/10.1111/joms.12325.

Hofmann, H., Schleper, M. C., \& Blome, C. (2018). Conflict minerals and supply chain due diligence: An exploratory study of multi-tier supply chains. Journal of Business Ethics, 147, 115-141. https:// doi.org/10.1007/s10551-015-2963-z.

Huq, F. A., \& Stevenson, M. (2018). Implementing socially sustainable practices in challenging institutional contexts: Building theory from seven developing country supplier cases. Journal of Business Ethics, 161, 415-442. https://doi.org/10.1007/s10551-018-3951-x.

Huq, F. A., Chowdhury, I. N., \& Klassen, R. D. (2016). Social management capabilities of multinational buying firms and their emerging market suppliers: An exploratory study of the clothing industry. Journal of Operations Management, 46, 19-37. https:// doi.org/10.1016/j.jom.2016.07.005.

ICMM. (2018). The Sustainable Development Goals: Making a positive contribution to the SDGs. Retrieved December 2, 2018, from https://www.icmm.com/en-gb/metals-and-minerals/making-apositive-contribution/sdgs.
Jain, T., Aguilera, R. V., \& Jamali, D. (2017). Corporate stakeholder orientation in an emerging country context: A longitudinal cross industry analysis. Journal of Business Ethics, 143, 701-719. https ://doi.org/10.1007/s10551-016-3074-1.

Jia, F., Zuluaga-Cardona, L., Bailey, A., \& Rueda, X. (2018). Sustainable supply chain management in developing countries: An analysis of the literature. Journal of Cleaner Production, 189, 263-278. https://doi.org/10.1016/j.jclepro.2018.03.248.

Kauppi, K. (2013). Extending the use of institutional theory in operations and supply chain management research. International Journal of Operations \& Production Management, 33, 1318-1345. https://doi.org/10.1108/IJOPM-10-2011-0364.

Kauppi, K., \& Hannibal, C. (2017). Institutional pressures and sustainability assessment in supply chains. Supply Chain Management: An International Journal, 22, 458-472. https://doi.org/10.1108/ SCM-01-2017-0004.

Ketokivi, M., \& Choi, T. (2014). Renaissance of case research as a scientific method. Journal of Operations Management, 32, 232-240. https://doi.org/10.1016/j.jom.2014.03.004.

Klassen, R. D., \& Vereecke, A. (2012). Social issues in supply chains: Capabilities link responsibility, risk (opportunity), and performance. International Journal of Production Economics, 140, 103-115. https://doi.org/10.1016/j.ijpe.2012.01.021.

Kovács, G., \& Spens, K. M. (2005). Abductive reasoning in logistics research. International Journal of Physical Distribution \& Logistics Management, 35, 132-144. https://doi.org/10.1108/09600 030510590318.

Kuckartz, U. (2016). Qualitative Inhaltsanalyse: Methoden, Praxis, Computerunterstützung (3rd ed., Grundlagentexte Methoden).

Lewin, K. (1943). Psychology and the process of group living. Journal of Social Psychology, 17, 113-131.

Lodhia, S., \& Hess, N. (2014). Sustainability accounting and reporting in the mining industry: Current literature and directions for future research. Journal of Cleaner Production, 84, 43-50. https://doi. org/10.1016/j.jclepro.2014.08.094.

Lydall, M. (2009). Backward linkage development in the South African PGM industry: A case study. Resources Policy, 34, 112-120. https ://doi.org/10.1016/j.resourpol.2009.01.001.

Marshall, D., McCarthy, L., Claudy, M., \& McGrath, P. (2019). Piggy in the middle: How direct customer power affects first-tier suppliers' adoption of socially responsible procurement practices and performance. Journal of Business Ethics, 154, 1081-1102. https ://doi.org/10.1007/s10551-016-3387-0.

Mayes, R. (2015). A social licence to operate: Corporate social responsibility, local communities and the constitution of global production networks. Global Networks, 15, 109-128. https://doi. org/10.1111/glob.12090.

Mayring, P. (2000). Qualitative content analysis. Forum: Qualitative Social Research, 1: 2.

Mayring, P. (2015). Qualitative Inhaltsanalyse: Grundlagen und Techniken (12th ed.). Weinheim: Beltz.

Meyer, J. W., \& Rowan, B. (1977). Institutionalized Organizations: formal structure as myth and ceremony. American Journal of Sociology, 83(2), 340-363.

Minerals Council South Africa. (2018). Facts and Figures: Pocketbook 2018: \#MakingMiningMatter. Retrieved Accessed March 8, 2019, from https://www.mineralscouncil.org.za/downloads/ send/18-current/682-facts-and-figures-2018.

New York Times. (2019). Why Did the Dam in Brazil Collapse? Here's a Brief Look.: That the dam fell was a tragedy. It should not have been a surprise. New York Times. Retrieved Accessed March 12, 2019, from https://www.nytimes.com/2019/02/09/world/americas/ brazil-dam-disaster.html.

Pagell, M., \& Shevchenko, A. (2014). Why research in sustainable supply chain management schould have no future. Journal of 
Supply Chain Management, 50, 44-55. https://doi.org/10.1111/ jscm.12037.

Pagell, M., \& Wu, Z. (2009). Building a more complete theory of sustainable supply chain management using case studies of 10 exemplars. Journal of Supply Chain Management, 45, 37-56. https:// doi.org/10.1111/j.1745-493X.2009.03162.x.

Palmer, D., Biggart, N., \& Dick, B. (2013). Is the new institutionalism a theory? In R. Greenwood, C. Oliver, R. Suddaby, \& K. SahlinAndersson (Eds.), The SAGE Handbook of Organizational (pp. 739-768). London: Sage.

Pfohl, H.-C., Köhler, H., \& Thomas, D. (2010). State of the art in supply chain risk management research: Empirical and conceptual findings and a roadmap for the implementation in practice. Logistics Research, 2, 33-44. https://doi.org/10.1007/s1215 9-010-0023-8.

Phillips, N., Tracey, P., \& Karra, N. (2009). Rethinking institutional distance. Strengthening the tie between new institutional theory and international management. Strategic Organization, 7(3), 339-348. https://doi.org/10.1177/1476127009337439.

Powell, W. W., \& Rerup, C. (2017). Opening the Black Box: The Microfoundations of Institutions. In R. Greenwood, C. Oliver, T. Lawrence, \& R. Meyer (Eds.), The SAGE Handbook of Organizational Institutionalism (pp. 311-337). London: Sage.

Quarshie, A. M., Salmi, A., \& Leuschner, R. (2016). Sustainability and corporate social responsibility in supply chains: The state of research in supply chain management and business ethics journals. Journal of Purchasing and Supply Management, 22, 82-97. https ://doi.org/10.1016/j.pursup.2015.11.001.

Quastel, N. (2011). "This is a Montreal Issue": Negotiating responsibility in global production and investment networks. Geoforum, 42, 451-461. https://doi.org/10.1016/j.geoforum.2011.03.012.

Rajak, D. (2012). Platinum city and the new South African dream. Africa, 82, 252-271. https://doi.org/10.1017/S0001972012000046.

Riege, A. M. (2003). Validity and reliability tests in case study research: A literature review with "hands-on" applications for each research phase. Qualitative Market Research: An International Journal, 6, 75-86. https://doi.org/10.1108/1352275031 0470055.

Sarkis, J., Zhu, Q., \& Lai, K.-H. (2011). An organizational theoretic review of green supply chain management literature. International Journal of Production Economics, 130, 1-15. https://doi. org/10.1016/j.ijpe.2010.11.010.

Sauer, P. C., \& Seuring, S. (2017). Sustainable supply chain management for minerals. Journal of Cleaner Production, 151, 235-249. https://doi.org/10.1016/j.jclepro.2017.03.049.

Sauer, P. S., \& Seuring, S. (2018). A three-dimensional framework for multi-tier sustainable supply chain management. Supply Chain Management: An International Journal, 23, 560-572. https://doi. org/10.1108/SCM-06-2018-0233.

Sauer, P. C., \& Seuring, S. (2019). Extending the reach of multi-tier sustainable supply chain management-Insights from mineral supply chains. International Journal of Production Economics, 217, 31-43. https://doi.org/10.1016/j.ijpe.2018.05.030.

Saunders, M., Lewis, P., \& Thornhill, A. (2012). Research methods for business students (6th ed.). Harlow: Pearson.

Sayed, M., Hendry, L. C., \& Zorzini Bell, M. (2017). Institutional complexity and sustainable supply chain management practices. Supply Chain Management: An International Journal, 22, 542-563. https://doi.org/10.1108/SCM-10-2016-0365.

Scott, W.-R. (1995). Institutions and organizations (6th ed., Foundations for organizational science). Thousand Oaks: SAGE.

Scott, W.-R. (1997). The institutional construction of organizations: International and longitudinal studies. Thousand Oaks: SAGE.

Silverman, D. (2013). Doing qualitative research (4th ed.). Los Angeles, CA: Sage.
Silverman, D. (2014). Interpreting qualitative data (5th ed.). Los Angeles, CA: Sage.

Silvestre, B. S. (2015). Sustainable supply chain management in emerging economies: Environmental turbulence, institutional voids and sustainability trajectories. International Journal of Production Economics, 167, 156-169. https://doi.org/10.1016/j. ijpe.2015.05.025.

Simpson, D., Power, D., \& Klassen, R. (2012). When one size does not fit all: A problem of fit rather than failure for voluntary management standards. Journal of Business Ethics, 110, 85-95. https:// doi.org/10.1007/s10551-011-1149-6.

Solomon, M. H. (2011). A conceptual approach to evaluating the political economics of mining in Africa and the sector's contribution to economic diversification. Journal of the South African Institute of Mining and Metallurgy, 111(7), 475-492.

Spence, L., \& Bourlakis, M. (2009). The evolution from corporate social responsibility to supply chain responsibility: The case of Waitrose. Supply Chain Management: An International Journal, 14, 291-302. https://doi.org/10.1108/13598540910970126.

Statistics-South Africa. (2015). Mining: Winners and losers of 2015. Retrieved Accessed December 2, 2016, from https://www.stats sa.gov.za/?p=6247.

Statistics-South Africa. (2016a). Mid-year population estimates. Retrieved Accessed March 16, 2019, from https://www.stats sa.gov.za/?page_id=1854\&PPN=P0302.

Statistics - South Africa. (2016b). Quarterly labour force survey: Quarter 3: 2016. Retrieved Accessed December 3, 2016, from https:// www.statssa.gov.za/? $\mathrm{p}=9095$.

Stuart, I., McCutcheon, D., Handfield, R., McLachlin, R., \& Samson, D. (2002). Effective case research in operations management: A process perspective. Journal of Operations Management, 20, 419-433. https://doi.org/10.1016/S0272-6963(02)00022-0.

Tracey, P., \& Phillips, N. (2011). Entrepreneurship in emerging markets: Strategies for new venture creation in uncertain institutional contexts. Management International Review, 51, 23-39. https:// doi.org/10.1007/s11575-010-0066-8.

UNDP. (2016). UNDP in South Africa: About South Africa. https ://www.za.undp.org/content/south_africa/en/home/countryinf o.html. Accessed 9 December 2016.

UNDP. (2018). Human Development Indices and Indicators 2018: Statistical Update (Human development report, Vol. 2018). New York: United Nations Development Programme.

Van de Ven, A. H. (1989). Nothings is quite so practical as a good theory. Academy of Management Review, 4(14), 486-489.

Vermeulen, W. J. V. (2013). Self-governance for sustainable global supply chains: Can it deliver the impacts needed? Business Strategy and the Environment, 24, 73-85. https://doi.org/10.1002/bse.1804.

Wijen, F. (2014). Means versus ends in opaque institutional fields: Trading off compliance and achievement in sustainability standard adoption. Academy of Management Review, 39, 302-323. https:// doi.org/10.5465/amr.2012.0218.

Wilhelm, M. M., Blome, C., Bhakoo, V., \& Paulraj, A. (2016). Sustainability in multi-tier supply chains: Understanding the double agency role of the first-tier supplier. Journal of Operations Management, 41, 42-60. https://doi.org/10.1016/j.jom.2015.11.001.

Wooten, M., \& Hoffman, A. J. (2013). Organizational fields: Past, present and future. In R. Greenwood, C. Oliver, R. Suddaby, \& K. Sahlin-Andersson (Eds.), The SAGE handbook of organizational (pp. 130-148). London: Sage.

World Bank. (2016). South Africa Economic Update: Promoting faster growth and poverty alleviation through competition. Retrieved Accessed December 5, 2016, from https://www.worldbank.org/en/ news/infographic/2016/02/01/promoting-faster-growth-and-pover ty-alleviation-through-competition.

Yawar, S. A., \& Kauppi, K. (2018). Understanding the adoption of socially responsible supplier development practices using 
institutional theory: Dairy supply chains in India. Journal of Purchasing and Supply Management, 24, 164-176. https://doi. org/10.1016/j.pursup.2018.02.001.

Yawar, S. A., \& Seuring, S. (2017). Management of social issues in supply chains: A literature review exploring social issues, actions and performance outcomes. Journal of Business Ethics, 141, 621643. https://doi.org/10.1007/s10551-015-2719-9.

Yin, R. K. (2014). Case study research: Design and methods (5th ed.). Los Angeles: SAGE.
Young, S. B. (2015). Responsible sourcing of metals: Certification approaches for conflict minerals and conflict-free metals. The International Journal of Life Cycle Assessment. https://doi. org/10.1007/s11367-015-0932-5.

Publisher's Note Springer Nature remains neutral with regard to jurisdictional claims in published maps and institutional affiliations. 